\title{
(a)

\section{Additive Manufacturing from the Point of View of Materials Research}

\author{
Ville Laitinen, Mabdi Merabtene, Erica Stevens, \\ Markus Chmielus, Jan Van Humbeeck, and Kari Ullakko
}

\section{INTRODUCTION}

Over the course of history, there have been three major industrial revolutions, each of them powered by the technological advances of the time and characterized by an increased productivity of industrial processes. Industry 1.0 incorporated the use of hydropower, steam power, and the

\footnotetext{
V. Laitinen $(\bowtie) \bullet$ M. Merabtene • K. Ullakko

Material Physics Laboratory, Lappeenranta-Lahti University of Technology LUT, Lappeenranta, Finland

e-mail: ville.laitinen@lut.fi; mahdi.merabtene@student.lut.fi; kari.ullakko@lut.fi

E. Stevens • M. Chmielus

Department of Mechanical Engineering and Materials Science, University of Pittsburgh, Pittsburgh, PA, USA

e-mail: ericastevens@pitt.edu; chmielus@pitt.edu

J. Van Humbeeck

Department of Materials Engineering, KU Leuven, Leuven, Belgium

e-mail: jan.vanhumbeeck@kuleuven.be

(C) The Author(s) 2020

M. Collan, K.-E. Michelsen (eds.), Technical, Economic and Societal

Effects of Manufacturing 4.0,

https://doi.org/10.1007/978-3-030-46103-4_3
} 
development of machine tools that enabled the mechanization of manufacturing processes; Industry 2.0 introduced mass production assembly lines that were powered by electrical energy; and Industry 3.0 introduced production automation, robots, and computer systems $[1,2]$. The key aspect of the ongoing industrial revolution, Industry 4.0, relates to the cyber-physical production systems that consist of physical machines controlled and interconnected by collaborating computational elements. In fact, Industry 4.0 is strongly influenced by our ability to process data, which has phenomenally increased over the past 15 years. In parallel with Industry 4.0, there also exists the concept of Materials 4.0 (or big data materials informatics), which incorporates the tools of cyber-physical space and materials informatics to enhance the design of materials and devices with targeted functionalities in a virtual environment through computational synthesis or reverse engineering from existing knowledge on materials $[3,4]$. This approach aims at a higher efficiency in synthesizing and testing novel material compositions and allows shorter lead times from conceptualization to production. However, as the concept of Materials 4.0 has been extensively reviewed in a recent article by [3], it is not discussed further in this chapter. Instead, we focus on the emerging topic of the additive manufacturing (AM) of metal-based stimuli-responsive materials and emphasize possible future directions for the additive manufacturing of metallic materials in general.

'Smart manufacturing' (later Manufacturing 4.0) is one of the primary concepts under Industry 4.0, and it can be described as an adaptable manufacturing system where production processes can adjust automatically for multiple types of products or changing conditions [1]. Manufacturing 4.0 incorporates a large group of base technologies, such as robots and other manufacturing automation, artificial intelligence, the internet of things, analytics and big data [2]. Additive manufacturing, also known as 3D printing, is without a doubt one of the key technologies empowering manufacturing under Industry 4.0. Additive manufacturing is a general term for technologies that are based on the layer-by-layer deposition of material according to a digital model of the object to be manufactured. Additive manufacturing offers many advantages, such as mass customization, reduced tooling costs, on-demand manufacturing, shorter lead times, reduced material waste, and the application-oriented optimization of geometries. In principle, additive manufacturing facilitates a greater freedom of design compared to traditional manufacturing technologies, which has opened up new ways to conduct engineering design. One of the central aspects in this development has been design for additive 
manufacturing (DFAM), which is a method that aims to consider additive manufacturing processes and material-related constraints in the design of components for additive manufacturing [5].

Besides freedom of design and enhanced shape complexity, another advantage of additive manufacturing relates to the materials themselves. Additive manufacturing is already today suitable for realizing complex geometries using several engineering materials, such as polymers, metals, ceramics, and composites [5-8]. Additive manufacturing has proven to be feasible for the processing of metallic materials, such as tungsten, which have been considered difficult to work with using conventional methods because of their high hardness and low ductility. In fact, for the last few years, pure tungsten has been commercially available for use in additive manufacturing systems made by EOS GmbH. Additionally, some additive manufacturing processes may introduce new options for metallic materials and enable the engineering and manufacturing of materials that are difficult or nearly impossible to synthesize using conventional methods. A good example of such materials are the so-called functionally graded materials, in which tailored properties can be obtained through a spatial gradation of chemical composition (gradient materials) and/or a 3D structure (hierarchical metamaterials). In addition, the size of these compositional or structural features can span multiple orders of magnitude. Furthermore, the introduction of new materials allows an expansion of the design space for additive manufacturing, which is interconnected with another interesting concept under Industry 4.0: the so-called 'smart materials' [9, 10].

Because materials themselves cannot be smart but can rather only exhibit certain intrinsic characteristics, the expressions 'smart materials' or 'intelligent materials' are typically (but not exclusively) used as an analogy to stimuli-responsive materials that can change their physical properties in response to external stimuli, such as a temperature change, mechanical stress, a magnetic field or an electrical current. In the scientific literature, stimuli-responsive materials are often divided into different classes based on their responses to an applied stimulus. Here, we entertain a similar approach and divide the stimuli-responsive materials into the four classes listed below.

- Stimuli-responsive actuator materials-materials that produce strain in response to the applied stimuli.

- Stimuli-responsive energy conversion materials-materials that exhibit an electric current, electrical resistance, magnetic field or temperature change as a primary response to the applied stimuli. 
- Stimuli-responsive optical materials - materials that exhibit an optical response, such as light emission or a change in optical properties, as a response to the applied stimuli.

- Stimuli-responsive state-changing materials - materials that alter their physical properties, such as viscosity, in response to the applied stimuli.

Examples of stimuli-responsive materials and some of their applications are listed in Table 1, based on research by [11-88]. Applications of stimuli-responsive materials under Industry 4.0 range from small actuators, sensors, and signalization devices all the way to photovoltaic materials used in the production of electricity from sunlight. In general, stimuliresponsive materials may yield a multitude of enhanced capabilities and functionalities for many products as these allow an active response to be achieved in a product that would otherwise lack it. Some examples of applications for stimuli-responsive materials under Manufacturing 4.0 are listed below; refer to Table 1 for specific examples and references.

- Materials that can generate significant mechanical motion with almost no other components besides the material itself have a high potential for replacing traditional mechanical components, such as the gears, shafts, and pulleys that are used to generate motion in conventional machines. Some of these materials, such as thermally activated shape memory alloys (SMAs) or magnetic shape memory alloys (MSMAs), can still produce motion below the size threshold where mechanical components or traditional mechanisms can no longer be used, thus offering a feasible application in different types of microelectromechanical systems. Additionally, some of these materials, such as the shape memory alloy $\mathrm{Ni}$-Ti or some of the shape memory polymers, are highly appreciated due to their biocompatibility for medical applications. Stimuli-responsive actuators can also be practical in any soft robotics that may be required for the handling of delicate or brittle materials or even living organisms.

- Some stimuli-responsive materials, such as magnetorheological liquids or the magnetic shape memory alloy Ni-Mn-Ga, may be practically useful in shock absorption and active vibration damping, for example in high-precision devices.

- Shape memory polymers can be used in active disassembly systems that are triggered at specific temperatures.

- Magnetocaloric materials can be used for high-efficiency magnetic cooling and refrigeration systems. 
Table 1 Classification of different types of stimuli-responsive materials and examples of their applications

\begin{tabular}{|c|c|c|c|c|c|}
\hline Class & Group & Stimulus & Response & Example materials & Example applications \\
\hline \multirow{11}{*}{$\begin{array}{l}\text { Stimuli- } \\
\text { responsive } \\
\text { actuator } \\
\text { materials }\end{array}$} & $\begin{array}{l}\text { Chemomechanical } \\
\text { polymers }\end{array}$ & $\begin{array}{l}\text { Chemical } \\
\text { reaction }\end{array}$ & Strain & Hydrogels [11] & $\begin{array}{l}\text { Delivery of drugs such as insulin, } \\
\text { artificial muscles, tissue engineering [11] }\end{array}$ \\
\hline & $\begin{array}{l}\text { Electroactive } \\
\text { polymers }\end{array}$ & Electric current & Strain & $\begin{array}{l}\text { Polyaniline, Nafion, polythiophenes, } \\
\text { poly(vinyl alcohol) gel with dimethyl } \\
\text { sulfoxide, poly(acrylonitrile) with } \\
\text { conductive fibers [12], polypyrrole, } \\
\text { poly(3,4-ethylene dioxythiophene) }[12,13]\end{array}$ & $\begin{array}{l}\text { Robotic applications, space } \\
\text { applications, biomimetic applications } \\
\text { [12], wearable sensors, prosthetic } \\
\text { applications, haptic sensing, pulse rate } \\
\text { monitoring, muscle movement } \\
\text { detectors [13] }\end{array}$ \\
\hline & Electrostrictive & Electric current & Strain & $\begin{array}{l}\text { Lead magnesium niobite }[14,15] \text {, barium } \\
\text { titanate }[16]\end{array}$ & $\begin{array}{l}\text { Piezo-actuator applications }[14,15] \text {, } \\
\text { actuators, transducers, energy } \\
\text { harvesters [17] }\end{array}$ \\
\hline & Magnetostrictive & Magnetic field & Strain & Metglas, Terfenol-D [18-20] & $\begin{array}{l}\text { Microwave devices, sensors, } \\
\text { transducers [18], sonar, ultrasonic } \\
\text { cleaning [20] }\end{array}$ \\
\hline & Photostrictive & Light & Strain & PLZT $[21,22]$ & $\begin{array}{l}\text { Non-contact actuation [21], wireless } \\
\text { remote control }[21,22]\end{array}$ \\
\hline & Shape memory alloys & \multicolumn{2}{|c|}{ Shape memory effect } & $\mathrm{Ni}-\mathrm{Ti}[23,24], \mathrm{Fe}-\mathrm{Mn}-\mathrm{Si}, \mathrm{Cu}-\mathrm{Zn}-\mathrm{Al}$, & Thermal actuators, couplings [23], \\
\hline & & Temperature & Strain & $\mathrm{Cu}-\mathrm{Al}-\mathrm{Ni}[23]$ & $\begin{array}{l}\text { dental implants, artificial heart valves } \\
{[23,24] \text {, active disassembly }[25,26]}\end{array}$ \\
\hline & Shape memory & \multicolumn{2}{|c|}{ Shape memory effect } & Polyurethane [27-29] & Active disassembly [30], ocular \\
\hline & polymer & $\begin{array}{l}\text { Temperature, } \\
\text { electric current, } \\
\text { light }\end{array}$ & Strain & & $\begin{array}{l}\text { implants, vascular stents, sutures [27], } \\
\text { self-tightening sutures [28], autochoke } \\
\text { elements, intravenous cannula [29] }\end{array}$ \\
\hline & Magnetic shape & \multirow{2}{*}{\multicolumn{2}{|c|}{$\begin{array}{l}\text { Shape memory effect } \\
\text { Magnetic shape memory effect }\end{array}$}} & $\mathrm{Fe}-\mathrm{Pd}[31,32], \mathrm{Ni}-\mathrm{Mn}-\mathrm{Ga}[33-35]$, & Micropumps [33], magnetic sensors, \\
\hline & memory alloys & & & Ni-Mn-Al [36], & energy harvesters $[32,35,37]$ \\
\hline
\end{tabular}




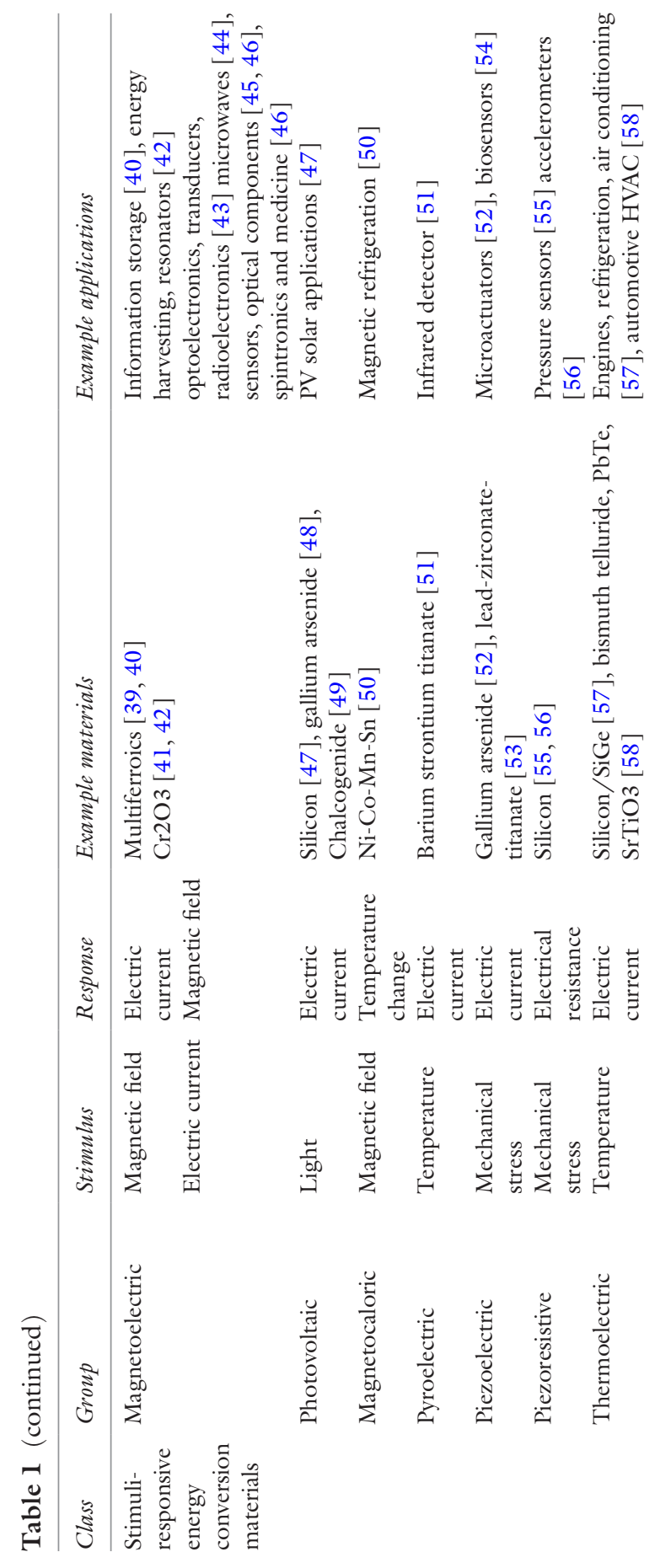




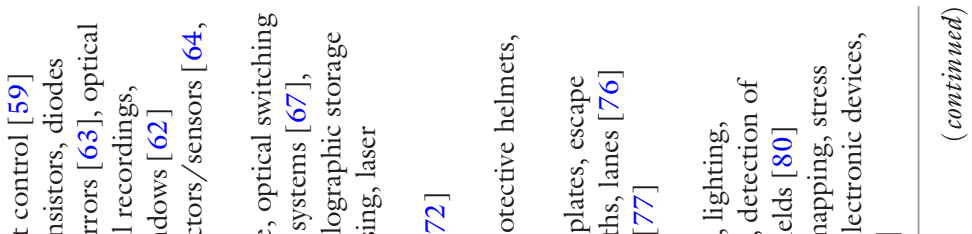

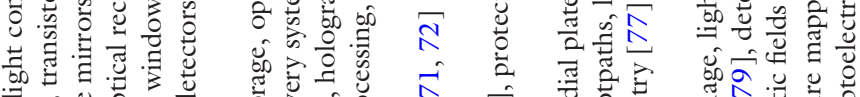

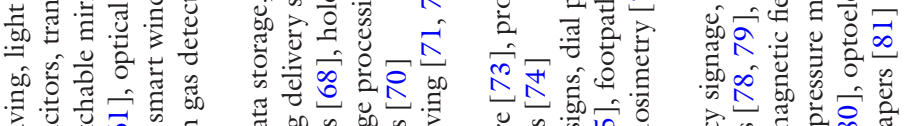

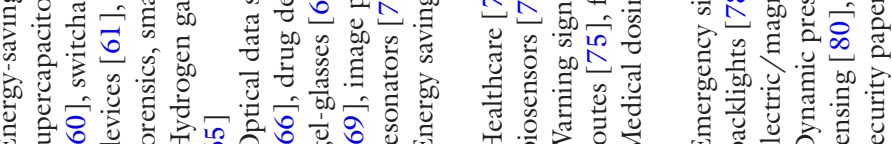

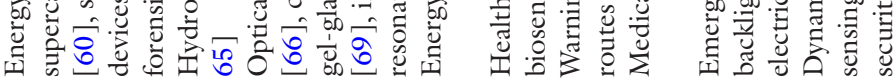

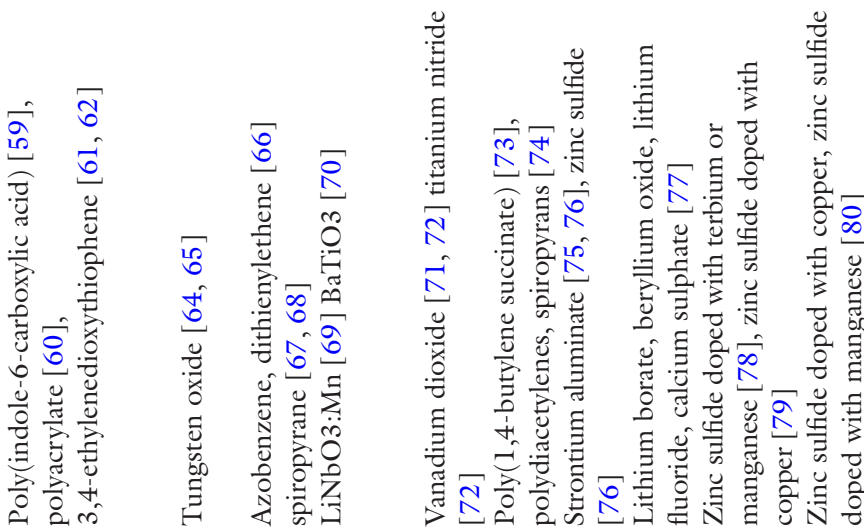

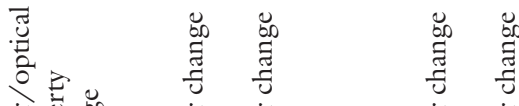

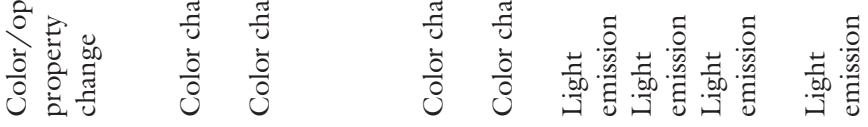
苛

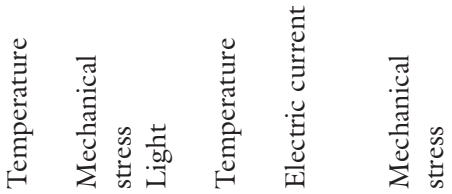

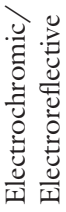
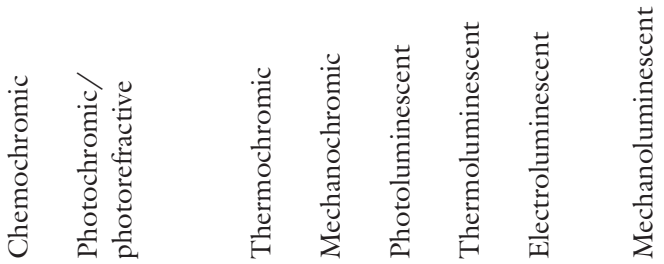

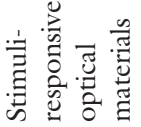




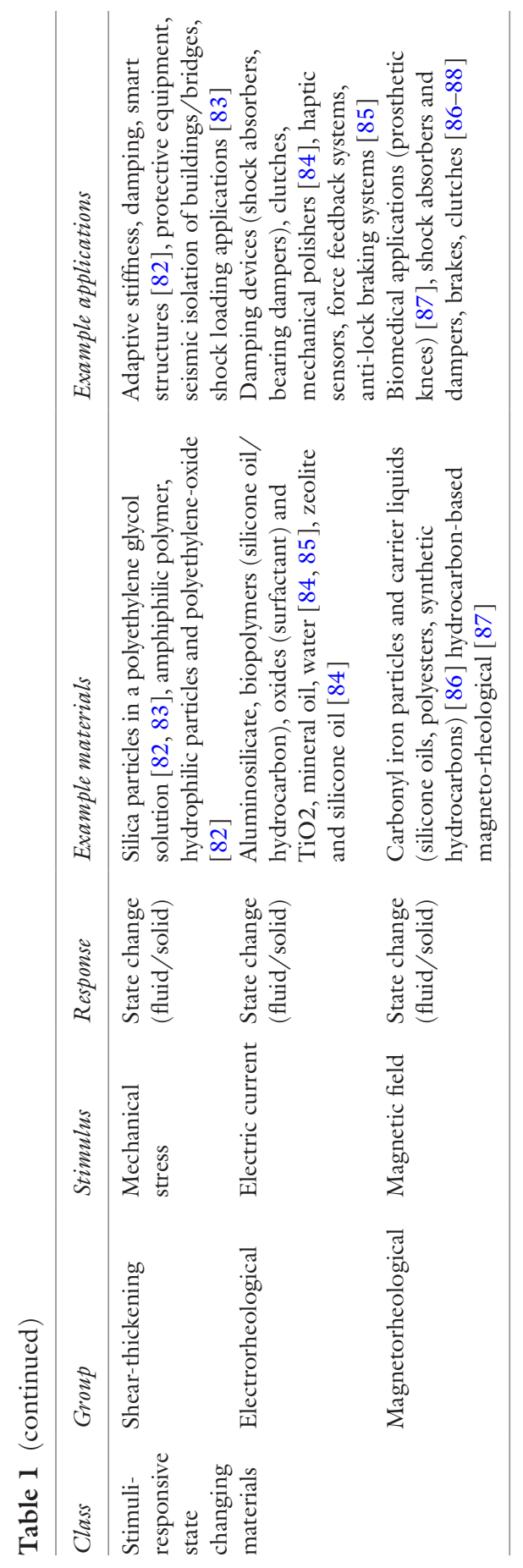


- Stimuli-responsive materials also have a high potential in different types of signalization devices, such as displays or haptic (sense of touch) technologies. In fact, haptic devices provide a unique interface between humans and machines, allowing remote distance operators to receive force feedback from the operated machines. For example, operators could receive information about the weight or resistance of lifted objects or be alerted when there is an issue with the operated machine.

- Another group of applications for stimuli-responsive materials under Industry 4.0 are different types of sensors, such as the ones used for failure detection and predictive maintenance in manufacturing systems. Additionally, wearable sensors are a prominent group of applications for many stimuli-responsive materials.

\section{Additive Manufacturing of Stimuli-Responsive Materials}

When it comes to stimuli-responsive materials, additive manufacturing is often referred to as $4 \mathrm{D}$ printing, which may refer to either the stimuliresponsive properties of the additively manufactured material in general or the ability of some of the materials (stimuli-responsive actuator materials) to change their physical shape in response to an applied stimulus. However, here we employ the term 'additive manufacturing of stimuli-responsive materials' instead of $4 \mathrm{D}$ printing as the usage of the former aligns better with the existing standardized terminology for additive manufacturing.

The additive manufacturing of different stimuli-responsive materials has gained significant interest in the past few years as this technology could facilitate a higher freedom of design concerning the stimuli-responsive properties of the manufactured objects. Tremendous advantages can be gained when devices can be optimized to fulfill the requirements of the intended application, instead of designing within the limits of the used manufacturing process. Thus, additive manufacturing may also accelerate the adoption of stimuli-responsive materials or expand their possible applications. Additionally, a combination of structural and stimuli-responsive materials under a single additive manufacturing process could enable the manufacturing of entire devices with integrated stimuli-responsive sections. In this case, certain functional characteristics or properties would be obtained locally in certain sections of the additively manufactured device. For example, in the case of stimuli-responsive actuator materials, the stimuli-responsive material would replace the traditional mechanisms within the manufactured device. These 'active regions' of the device could be 
actuated using a passive source of energy, such as a magnetic field in the case of magnetic shape memory alloys or heat in the case of thermally activated shape memory alloys. Additionally, additive manufacturing could allow a localized tailoring of properties (as in Fig. 1) within a single device,

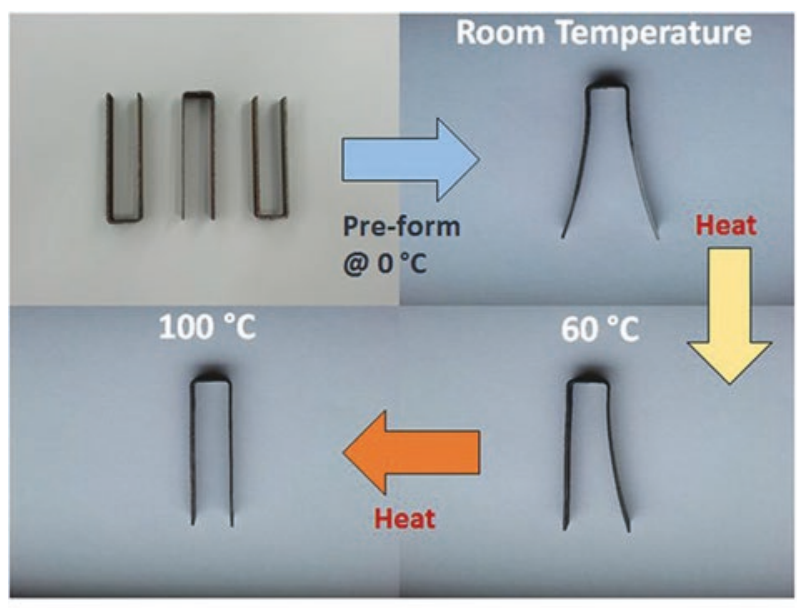

a

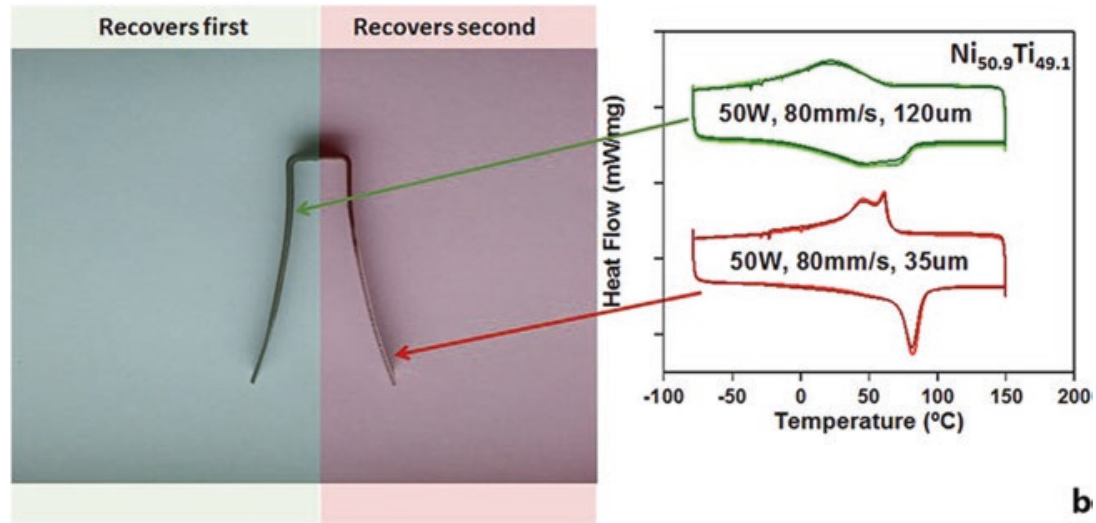

Fig. 1 (a) A location-dependent active response generated by temperaturedependent multi-stage shape recovery in a U-shaped $\mathrm{Ni}$-Ti component deposited using L-PBF; (b) effect of the L-PBF process parameters on the transformation temperatures and active responses at different sections of the build. Reproduced from [151] under Creative Commons Attribution 4.0 International License 
for example by inducing local differences in composition or microstructure in the processed stimuli-responsive material. Overall, these developments could facilitate the additive manufacturing of entire devices with embedded actuators or sensors, which could act as functional parts in existing systems, such as in soft robotics or pneumatics.

The majority of the published reviews on the additive manufacturing of stimuli-responsive materials have focused on shape memory polymers [152-161], while a few articles [162-167] have discussed aspects of expanding the DFAM method towards the adoption of these materials in additively manufactured components. Although some reviews have also discussed the additive manufacturing of thermally activated shape memory alloys, reviews concerning other metal-based stimuli-responsive materials, such as magnetic shape memory alloys or magnetocaloric materials, are sparse to non-existent. The popularity of polymer-based materials is expected because they are more feasible for low-cost additive manufacturing in comparison to metal-based materials, which are more difficult to manufacture additively without defects. Hence, this chapter concentrates on the additive manufacturing of thermally activated shape memory alloys, magnetic shape memory alloys, and magnetocaloric alloys. A brief overview of the state of the art in the additive manufacturing of these materials is presented in Table 2, based on the research results from [89-150]. An overview of the main additive manufacturing process categories (compared to the additive manufacturing processes in Table 2) for metal-based stimuli-responsive materials is presented below, following the definitions given in standard SFS-EN ISO/ASTM 52900:2017.

- Material extrusion - "An additive manufacturing process in which material is selectively dispensed through a nozzle or orifice"; an example process for metals is $3 \mathrm{D}$ ink printing, whereby metal powder is dispensed in a mixture with a bonding agent.

- Powder bed fusion - "An additive manufacturing process in which thermal energy selectively fuses regions of a powder bed"; the applied thermal energy can be either a laser (L-PBF) or an electron beam (E-PBF).

- Binder jetting - "An additive manufacturing process in which a liquid bonding agent is selectively deposited to join powder materials".

- Divected energy deposition - "An additive manufacturing process in which focused thermal energy is used to fuse materials by melting as they are being deposited"; example processes include laser-based directed energy deposition of powder material (L-DED), plasma arc deposition (PAD), and wire and arc additive manufacturing (WAAM). 


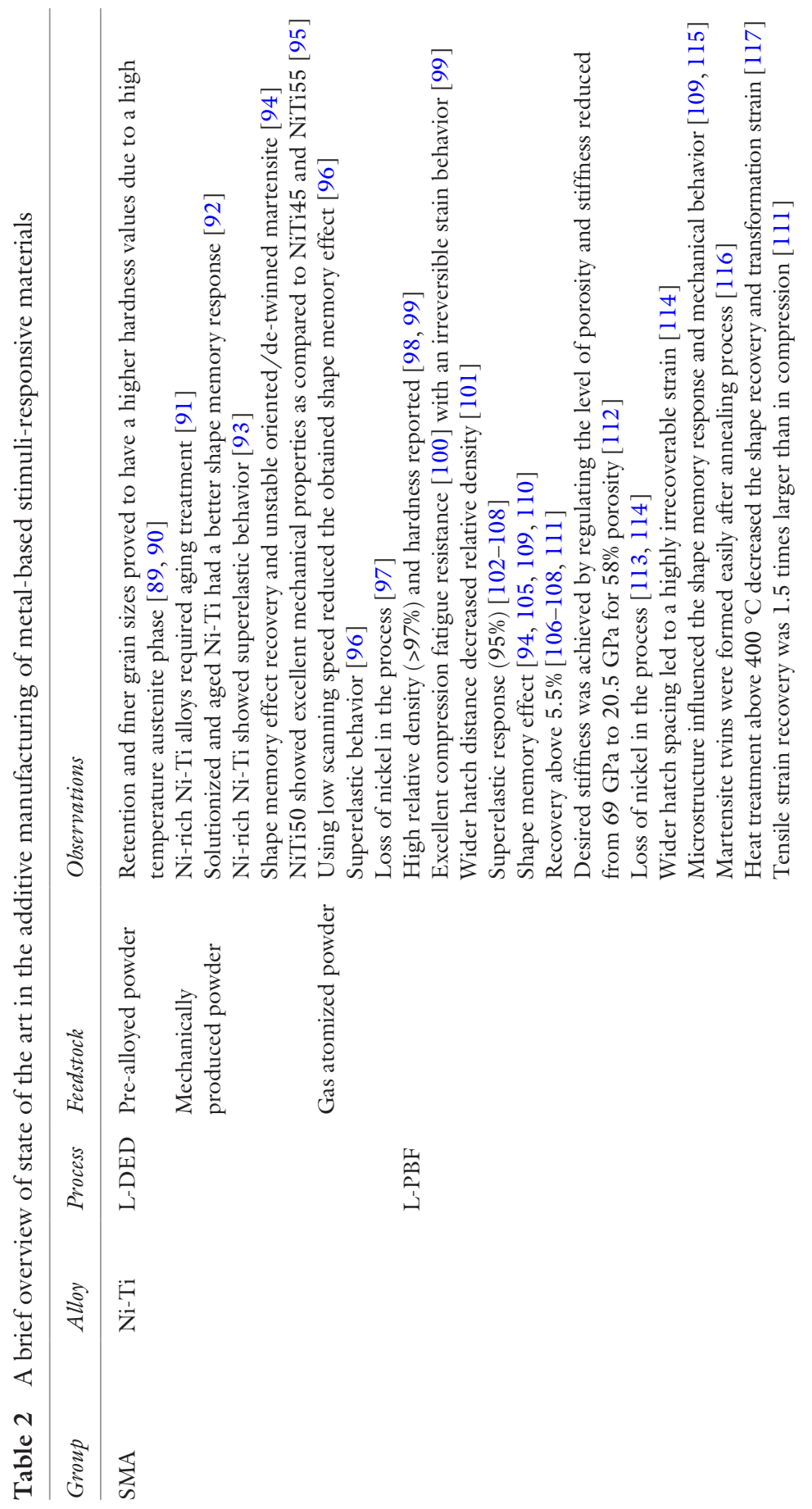




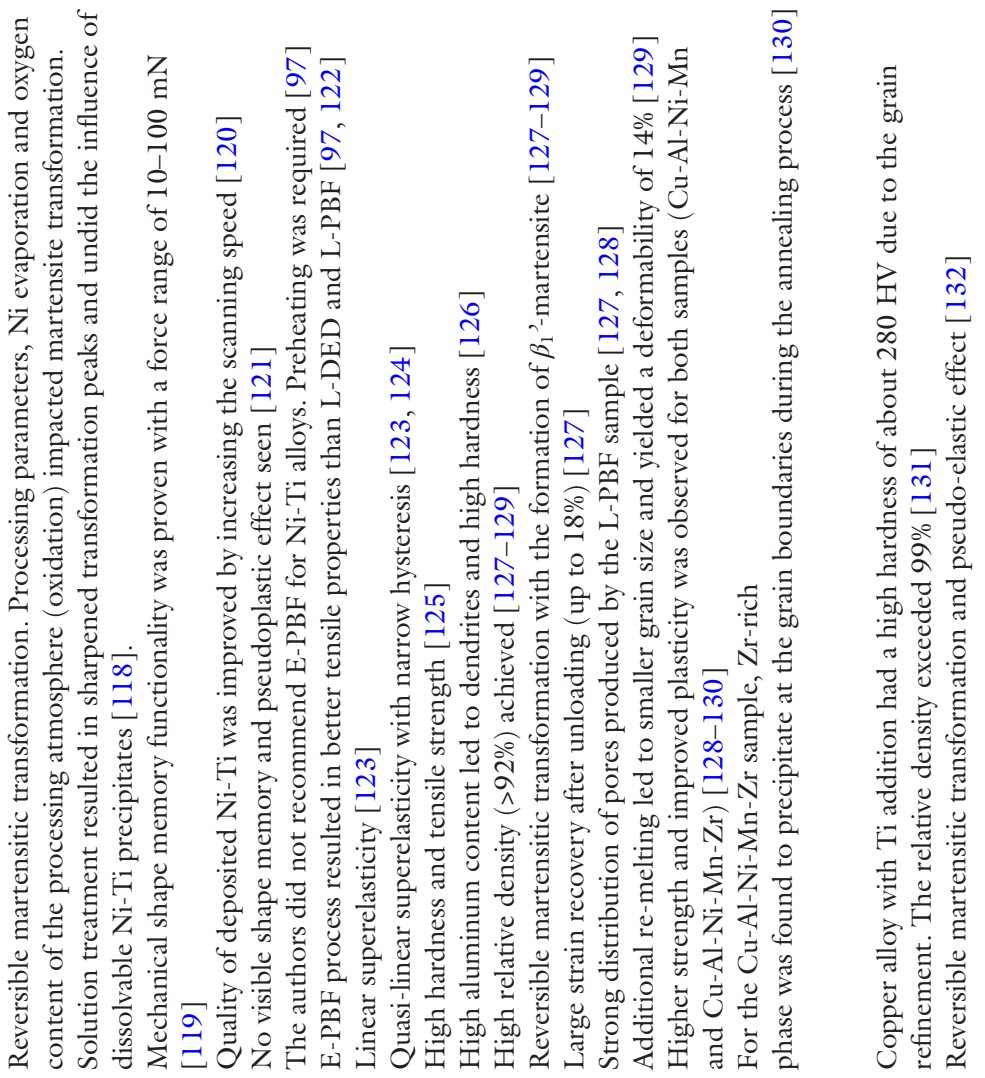

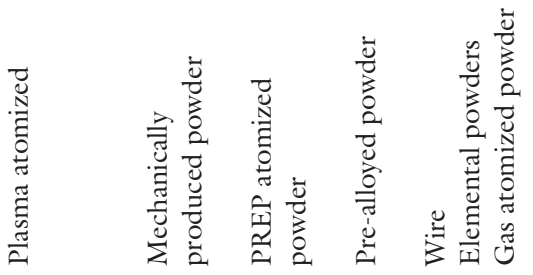

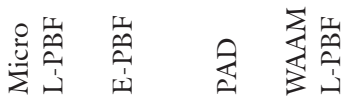

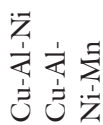

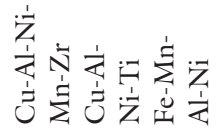




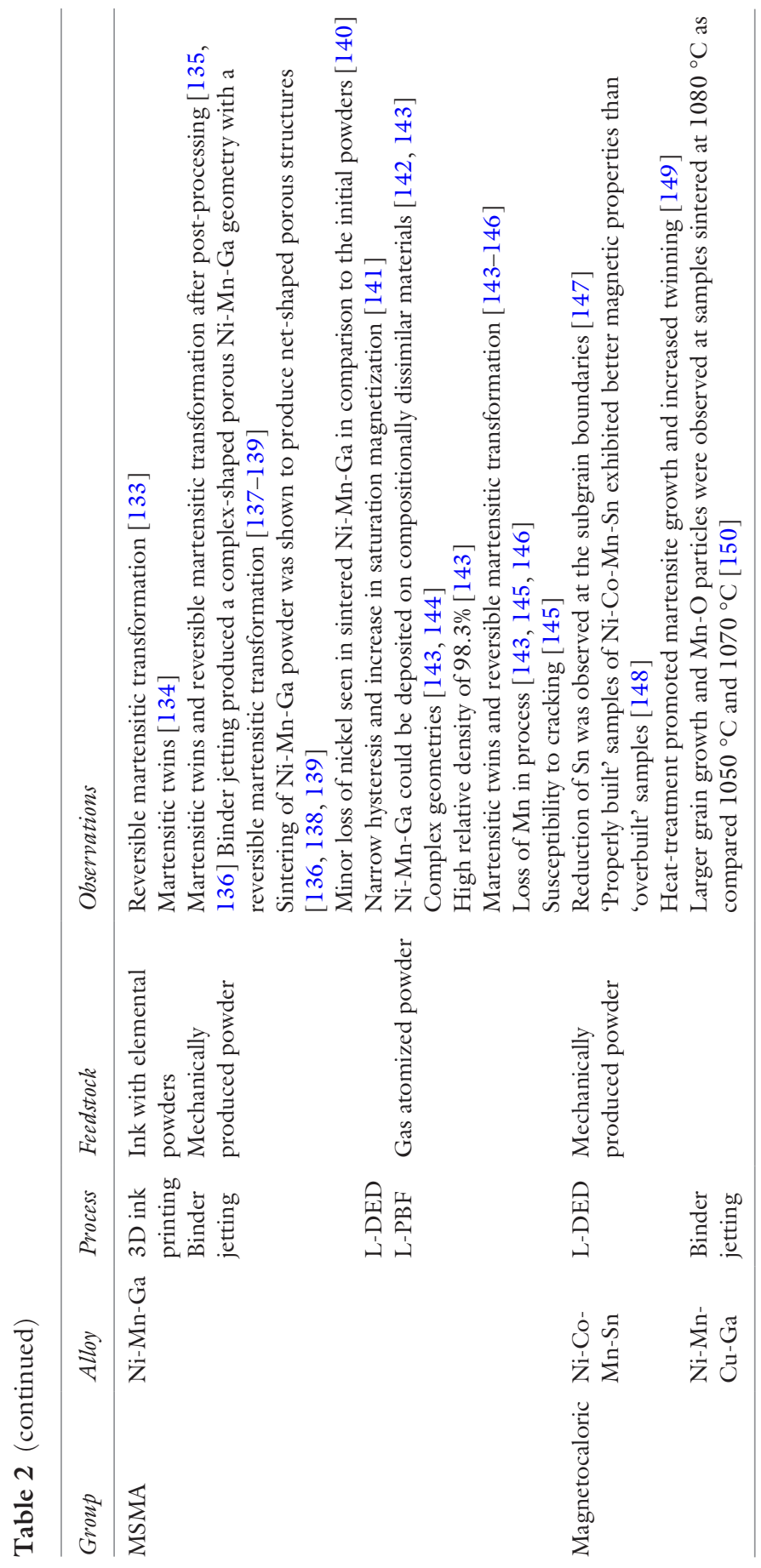




\section{Additive Manufacturing of Shape Memory Alloys}

Shape memory alloys are alloys that can recover a limited applied strain of less than 10\% either thermally or mechanically [168]. This property finds its origin in a thermoelastic martensitic transformation in some particular alloys. This transformation is characterized by its transformation temperatures $\left(\mathrm{M}_{\mathrm{s}}, \mathrm{M}_{\mathrm{f}}\right.$ during cooling reaching the martensitic phase, $\mathrm{A}_{\mathrm{s}}, \mathrm{A}_{\mathrm{f}}$ during heating reaching the beta phase), exhibiting a relatively small hysteresis of about 10-40 K compared to the well-known martensitic transformation in many steels exhibiting a hysteresis of several $100 \mathrm{~K}$. When a strain, limited to $10 \%$, is applied in the martensitic state, this strain can be recovered by heating above the transformation temperature into the beta phase. This is called the thermal recovery or shape memory effect. When a strain of less than $10 \%$ is applied in the beta phase, above $M_{s}$, the strain is mechanically recovered upon releasing the applied stress, which is called superelasticity. Complete thermal or mechanical recovery can only be obtained in a limited temperature window around the martensitic transformation. The thermally activated shape memory effect occurs in some $\mathrm{Cu}$-based alloys and Fe-based alloys, but it is mostly associated with $\mathrm{Ni}$-Ti alloys. $\mathrm{Ni}$-Ti is superior compared to other shape memory alloys for many reasons, including its high ductility, high strength, and very fine grain size. These properties enable the production of very thin devices (wires with a diameter down to $25 \mu \mathrm{m}$ ). Additionally, it is biocompatible, which is why more than $80 \%$ of the products made of $\mathrm{Ni}-\mathrm{Ti}$ are medically related [169]. Besides their use in medical applications, shape memory alloys can convert heat into a high force or work output, which makes these alloys useful in the actuators of stress-creating components [23, 170].

From the perspective of conventional manufacturing processes, a major problem of $\mathrm{Ni}-\mathrm{Ti}$ is its poor machinability, primarily due to the strong strain hardening effect. Thus, wire and tube drawing are the most common applied forming techniques used in the production of devices such as guise wires, stents, and actuators based on springs. This sets many limitations on the shape complexity of the manufactured devices. Therefore, additive manufacturing of $\mathrm{Ni}$-Ti has gained the attention of designers of medical and other devices. As shown in Table 2, laser-based processes, especially L-PBF, are the most typical approach for the additive manufacturing of Ni-Ti. The same observation applies to $\mathrm{Cu}$ - and $\mathrm{Fe}$-based alloys, although little scientific literature is available on the additive 
manufacturing of these materials. In fact, the future for $\mathrm{Cu}$-based SMAs does not look bright as the majority of research on additive manufacturing of SMAs concentrates on Ni-Ti. However, the additive manufacturing of $\mathrm{Ni}$-Ti represents only a small fraction of the medical applications produced by metal-based additive manufacturing, and only a handful of studies on the additive manufacturing of $\mathrm{Ni}$ - $\mathrm{Ti}$ consider its stimuli-responsive properties, such as the very low stiffness (very low E-modulus), and its functional properties, such as superelasticity and the shape memory effect. However, a fair amount of research on the laser additive manufacturing (LAM) of Ni-Ti shape memory alloys has been conducted [23, 115, 171-174]. Therefore, we summarize here the most important observations of Ni-Ti deposited using L-PBF, as previously discussed by [173] and briefly overviewed in Table 2 .

- Although Ni-Ti can be processed at a high density crack-free, the mechanical and functional properties of the processed material are on average inferior compared to the wrought material. However, using repetitive laser scanning in the process may allow improvement of the functional properties of deposited Ni-Ti.

- Controlling the transformation temperatures of the processed material is difficult, mainly due to the evaporation of $\mathrm{Ni}$ and precipitation based on impurities. Hence, the composition and transformation temperatures of the processed material are strongly dependent on the processing parameters and, therefore, the transformation temperatures of the final product are not necessarily the transformation temperatures of the initial powder.

- Additionally, the processing environment should be controlled to prevent oxygen and/or nitrogen pick-up that may lead to an increased density of impurities, which may influence the transformation temperatures and the mechanical properties of the processed material.

- The surface roughness of the final product should be considered in relation to potential wear or for the difficulties it causes in sterilization, which is required for biomedical applications. 


\section{Additive Manufacturing of Magnetic Shape Memory Alloys}

Besides the thermally activated shape memory effect, magnetic shape memory (MSM) alloys may also exhibit a straining phenomenon when the magnetic moments of the martensitic twin variants of the alloy align with the applied magnetic field $[38,175,176]$. This straining phenomenon is called the magnetic shape memory effect. The Ni-Mn-Ga system, which is the most studied class of MSM materials, has been shown to exhibit outstanding characteristics, such as magnetic-field-induced strains (MFIS) of $12 \%$ [176], which is a hundred times larger than the magnetically induced strains obtained in competing materials. In addition, the efficiency (mechanical work output / magnetic field energy) of the MSM effect can be over $95 \%$ and its fatigue life can exceed $2 \times 10^{9}$ cycles [177]. Characteristic of the MSM materials is that the strain remains unchanged after the magnetic field has been switched off (the strain can be recovered by applying a magnetic field in transversal direction or by force). This results in significant energy savings in many applications, especially on-off valves, because magnetic field energy is needed only during the brief time when the shape of the MSM element is changed. Additionally, Ni-Mn-Ga can exhibit high strain accelerations of $1.6 \times 10^{6} \mathrm{~m} / \mathrm{s}^{2}$ [178], which is assumed to be the highest acceleration of all actuator materials. These characteristics may be beneficial in several applications, such as in robotics, biomedical applications and optics. For instance, fast actuators/sensors [34, 176], micropumps [33], and vibration energy harvesters [35] have been identified as potential applications for MSM materials. However, commercial applications of MSM materials are still limited, possibly due to the relatively young age of the technology itself compared to competing piezo ceramics or giant magnetostrictive materials.

Typically, bulk polycrystalline Ni-Mn-Ga does not exhibit limited MFIS due to grain boundary constraints that effectively block twin boundary motion in the material. However, directionally solidified (textured) polycrystalline Ni-Mn-Ga has been shown to exhibit up to $1.0 \%$ strain [179], whereas polycrystalline $\mathrm{Ni}-\mathrm{Mn}-\mathrm{Ga}$ foam has been shown to exhibit up to $8.7 \%$ recoverable strain [180]. A smaller force output and brittleness are disadvantages of foamy polycrystalline compared to more conventional single-crystalline material. From a manufacturing perspective, the use of additive manufacturing offers better freedom of design, especially compared to typical single-crystalline material. Thus, the additive 
manufacturing of MSM alloys aims at obtaining parts with controlled porosity while facilitating the possibility to manufacture complex geometries. Additionally, additive manufacturing places fewer limitations on the size of the manufactured object. Other advantages that may be potentially gained through additive manufacturing relate to the possibility to produce compositional gradients that allow for the tailoring of the properties for specific applications.

Compared to the additive manufacturing of Ni-Ti based thermally activated shape memory alloys, additive manufacturing of magnetic shape memory alloys is still in its infancy. All the scientific literature available at the time focuses on the additive manufacturing of Ni-Mn-Ga-based MSMAs. The most common approaches on additive manufacturing of $\mathrm{Ni}-\mathrm{Mn}-\mathrm{Ga}$ have concentrated on 3D ink printing [133, 134] and binder jetting [135-140]. However, also a few investigations into manufacturing of polycrystalline Ni-Mn-Ga using L-DED [141] and L-PBF [142-146] have recently been published. Each of the aforementioned processes have their own advantages and disadvantages concerning the manufacture of a material that exhibits MFIS. Nevertheless, a common aspect for all of the processes is the aim to obtain controlled composition, microstructure and porosity, which is essential for obtaining MFIS in polycrystalline Ni-Mn-Ga. Especially, assuring the chemical integrity of the manufactured material is also important because of the high susceptibility of the crystal structure of $\mathrm{Ni}-\mathrm{Mn}-\mathrm{Ga}$ to compositional variation and impurities.

In general, both 3D ink printing and binder jetting processes have been proven to be feasible for producing Ni-Mn-Ga with complex geometries. However, binder-based processes face a challenge regarding the control of the composition and microstructure because the consistent removal of binder elements post-processing is difficult and some oxidation and $\mathrm{Mn}$ evaporation may occur during the sintering process [139]. LAM processes base on melting the material, thus enabling the use of binders to be avoided. However, previous studies on the L-PBF of Ni-Mn-Ga show that some $\mathrm{Mn}$ is lost in the process and that this Mn loss is strongly influenced by the used process parameters [143-145]. In fact, loss of Mn during the $\mathrm{L}-\mathrm{PBF}$ process is expected due to the high vapor pressure and low boiling temperature of $\mathrm{Mn}$ in comparison to the other elements in the alloy. Thus, control over the processing parameters and the thermal cycle that the processed material undergoes is critical for obtaining a controlled composition. This may also be an advantage, as the composition could be controlled through an adjustment of the process parameters, which could potentially 
allow for the adjustment of the microstructure and stimuli-responsive properties of the processed material. However, excessive over-alloying of $\mathrm{Mn}$ into the used powder would be required for this approach to be feasible.

The control of the porosity in the additive manufacturing of $\mathrm{Ni}-\mathrm{Mn}-\mathrm{Ga}$ has typically based on manufacturing different types of lattice structures $[133,137,142]$ or foam-like materials $[134,138]$. Additionally, the sintering process used in binder-based additive manufacturing processes can also be adjusted to control the density of the processed material [140]. The processed material undergoes a repetitive cycle of heating and cooling in LAM processes as the heat from melting is conducted through the prior layers of deposited material. As a result, the processed material may exhibit regions with different thermal histories, which also affects the local microstructures. This has been observed as broad ferromagnetic hysteresis and wide phase transitions in as-deposited material [141, 143]. Additionally, $\mathrm{Ni}-\mathrm{Mn}$-Ga processed by L-PBF may exhibit cracking [145]. Post-process heat-treatment is required to retain the typical ferromagnetic behavior and material properties in the deposited material [141, 143, 144]. However, laser-based processes typically produce a microstructural texture [181], which is considered beneficial for obtaining MFIS.

Although additive manufacturing shows high potential for facilitating greater design freedom for MSM based devices, so far the functional properties of the additively manufactured material are inferior compared to the conventional oriented single crystals or textured polycrystalline material. By so far, Ni-Mn-Ga processed by binder jetting [136] and L-PBF [142] have been shown to develop a magnetically induced strains up to $0.01 \%$, which are significantly lower than the $8.7 \%$ achieved in Ni-Mn-Ga based foams [180]. In conclusion, more research on additive manufacturing of MSM alloys is required for understanding relationships between the applied process parameters and the resulting functional properties.

\section{Additive Manufacturing \\ of Magnetocaloric Materials}

Some materials experience a change in entropy $\left(\Delta \mathrm{s}_{\mathrm{T}}\right)$ when exposed to a magnetic field in an isothermal environment due to a phase change of either the first or second thermodynamic order [182-184]. When placed in an adiabatic environment instead, this magnetic-field-induced phase 
change produces a temperature change $\left(\Delta \mathrm{T}_{\mathrm{ad}}\right)$ in the material, leading to the common designation of this phenomenon as the magnetocaloric effect [185]. The magnetocaloric effect can be observed in both first- and second-order materials, with the order parameter of magnetization. In a firstorder material, the change in magnetization is discontinuous at the transformation, whereas the change in magnetization for a second-order material is gradual and continuous over the transformation. In the case of a second-order material, this magnetization change is caused by an alignment of magnetic moments around the Curie temperature (demagnetization temperature), reducing the magnetic entropy with increasing magnetic field and causing a corresponding increase in the thermal entropy. The entropy trade-off concept remains for first-order materials, but with the addition of a magnetostructural (or magnetoelastic) phase transformation that causes the direction of the entropy change with the addition of an applied field to be less straightforward. Near the transformation temperature, an applied magnetic field will stabilize the more magnetic phase, which could be either the high-temperature or the low-temperature phase. If the high-temperature phase is stabilized, the application of a magnetic field shifts the transition to lower temperatures and leads to a decrease in the temperature of the material-called the negative (or inverse) magnetocaloric effect. If the low-temperature phase is stabilized, the application of a magnetic field shifts the transition to higher temperatures and leads to an increase in the temperature of the material-the positive magnetocaloric effect.

Recently, the magnetocaloric effect has been researched for leverage in heat pumps, particularly for cooling in applications such as solid-statebased magnetic refrigeration requiring no harmful refrigerants and in localized hypothermia therapy to treat cancer [186, 187]. For the most common application of refrigeration, any magnetocaloric effect-exhibiting material that is to be considered a viable option as a heat exchanger within a heat pump must be formed with a high surface-to-volume ratio and must allow satisfactory fluid flow [188, 189]. Thus, the following two requirements are placed upon the heat exchanger [190]:

1. Maximize the volume fraction of the magnetocaloric effect material while maintaining a large surface area.

2. Minimize the pressure drop in the fluid across the heat exchanger. 
Common methods for producing heat exchanger devices from magnetocaloric effect materials are [190]: packed powder beds [191-193], parallel plates [194-197], and microchannel systems [198]. Packed powder beds, though cheap and simple, have a high pressure drop across the device due to the presence of turbulent flow. Microchannels, though inducing only a low drop in fluid pressure, have a high manufacturing cost (if they can be currently manufactured at all for the given material). Parallel plate devices are a median between the two extremes, allowing for a fluid flow that is not as turbulent as in packed powder beds and a production that is not quite as expensive as with microchannels.

With an abundance of requirements on both the feedstock material and the final magnetocaloric-effect-based heat exchanger, fabrication complications are an inescapable challenge. For example, first-order phase transition materials tend to be brittle, which limits the ability to machine them into desired geometries [199]. Difficulties with fabrication can leave promising alloys showing only a modest magnetocaloric effect after device fabrication due to changes in microstructure or atomic ordering and defects $[200,201]$. In addition, first-order phase transition magnetocaloric effect materials have narrow operating temperature windows [200, 202]. For ideally efficient operation, a heat exchanger using the first-order phase transition magnetocaloric effect must have stages or a gradient of material transformation temperatures [198]. With a transformation temperature gradient, the fluid will heat (or cool) as it passes through the series of materials, at each point existing within the operating temperature for the magnetocaloric effect material that it is currently in contact with. Second-order phase transition materials are less difficult to shape and have a wider operating temperature range, but the most promising material $(\mathrm{Gd})$ is a 'critical material' as it is costly, has a high environmental impact, and its use in a large number of cooling applications would lead to demand far exceeding supply $[190,199,203]$.

As a manufacturing method, additive manufacturing may allow for the inclusion of designed, multi-scale porosity; complicated geometries impossible with other methods; the processing of brittle materials that cannot be machined; and gradient or layered materials with gradient or staged material transformation temperatures. This combination of benefits can grant the ability to fulfill both heat exchanger requirements with no trade-offs: a minimal pressure drop across a material that has a high surface-to-volume ratio with a maximized volume of functional material present to produce a large temperature change across a wide temperature range. 
Additive manufacturing for magnetocaloric materials is in its relative infancy, although it is increasingly being recognized as a potential production avenue for magnetocaloric effect materials. In 2013, [204] used selective laser melting to create heat exchangers from $\mathrm{La}(\mathrm{Fe}, \mathrm{Co}, \mathrm{Si})_{13}$. Meanwhile, [137, 139, 147, 148, 150] conducted experiments with Ni-Mn-based Heusler alloys fabricated using L-DED and powder bed binder jet 3D printing. L-DED, with a laser as the energy source, required a heat treatment to homogenize the microstructure before promising properties were observed [147, 148]. Binder jet printing, since it requires no heat input that would change the feedstock powder's microstructure, showed a magnetocaloric response in the as-sintered state [150] [133]. used inkjet printing to deposit a mixture containing elemental $\mathrm{Ni}, \mathrm{Mn}$, and Ga powders, then sintered them to create final lattice structures with $73-75 \%$ porosity in the micro-trusses. Published experimental studies are scarce compared to the literature on the additive manufacturing of structural metals. Nevertheless, as discussed here and in [190, 199], with the proper attention to tailoring the processing to maintain the functional properties and with measures taken to balance cost and effectiveness, additive manufacturing is a promising technology to address current manufacturing and design issues while at the same time improving the overall performance of magnetocaloric structures.

\section{Future Aspects of Additive Manufacturing for Novel Metallic Materials}

Besides enabling advances in freedom of design and the processing of stimuli-responsive alloys, additive manufacturing may allow the development and manufacturing of customized, application-specific materials and could thus enable the expansion of the exciting material box of different metal alloys. For example, recent developments have been made in the additive manufacturing of metal matrix composites and high-entropy alloys [8], which are favored for their outstanding mechanical properties. Additionally, significant progress has been made in engineering and manufacturing functionally graded materials, such as gradient materials or metamaterials [205-209]. A common additive manufacturing process for the fabrication of compositional gradient materials is DED, which offers unique capabilities, such as the deposition of more than one material simultaneously or the changing of the deposited material from layer to 
layer. A second advantage of DED is that the build process itself is not limited, compared to PBF, where deposition is only possible in successive horizontal layers. This makes the DED process suitable for depositing material on $3 \mathrm{D}$ substrates, such as existing parts. In fact, repairing a worn part or tool represents a typical industrial application for this process. In principle, this type of additive manufacturing process allows a precise small-scale synthesis of materials during the manufacturing process itself, thus enabling the manufacturing of materials that are difficult to synthesize on a larger scale using conventional methods. Besides potentially allowing the creation of new alloys, this also enables the application-specific tailoring of the materials of the manufacturing process itself, which could be practical for on-demand manufacturing [210]. Additionally, LAM enables the composition and microstructures to be adjusted via the process parameters, which allows the integration of information within the processed material [211]. This could be used to enhance the traceability of the used materials or processes or of the 'smart products' themselves.

\section{SUMMARY}

In this chapter, we discussed how additive manufacturing could contribute to metal-based stimuli-responsive materials and material science in general. Although the future looks bright, substantial research is still required to extend the range of 'printable' materials and to achieve appropriate stimuli-responsive properties in additively manufactured metalbased materials. The complexity of the production and the material parameters create large challenges in producing dense, defect-free materials using the associated additive manufacturing processes. Indeed, specific processing conditions of metal additive manufacturing are challenging, and many material systems still suffer from cracks, unwanted porosity, high internal stresses, bad surface quality, and mechanical properties below the required levels. In many cases, this creates the need for post-processing, such as hot isostatic pressing (HIP), stress relieving, thermal treatments or polishing. However, additive manufacturing facilitates a great amount of design freedom for complex geometries and in some cases may enable the tailoring of compositional properties of the processed materials to an extent that is almost impossible to achieve using conventional manufacturing methods. Hence, additive manufacturing has a high potential for the development of novel types of stimuli-responsive devices. 


\section{REFERENCES}

1. Frank A, Dalenogare L, and Ayala N (2019) Industry 4.0 technologies: Implementation patterns in manufacturing companies. Int J Prod Econ 210:15-26. https://doi.org/10.1016/j.ijpe.2019.01.004.

2. Alcácer V, Cruz-Machado V (2019) Scanning the Industry 4.0: A Literature Review on Technologies for Manufacturing Systems. Eng Sci Technol Int J 22(3):899-919. https://doi.org/10.1016/j.jestch.2019.01.006.

3. Jose R, Ramakrishna S (2018) Materials 4.0: Materials big data enabled materials discovery Appl Mater Today 10:27-132. https://doi. org/10.1016/j.apmt.2017.12.015.

4. Ramakrishna S, Zhang T, Lu W, Qian Q, Low J, Yune J, Tan D, Bressan S, Sanvito S, Kalidindi S (2018) Materials informatics. J Intell Manuf 30(6):2307-2326. https://doi.org/10.1007/s10845-018-1392-0.

5. Thompson M, Moroni G, Vaneker T, Fadel G, Campbell R, Gibson I, Bernard A, Schulz J, Graf P, Ahuja B, Martina F (2016) Design for Additive Manufacturing: Trends, opportunities, considerations, and constraints. CIRP Ann 65(2):737-760. https://doi.org/10.1016/j.cirp.2016.05.004.

6. Gibson I, Rosen D, Stucker B (2015) Additive Manufacturing Technologies: 3D Printing, Rapid Prototyping, and Direct Digital Manufacturing. Springer, New York.

7. Bourell D, Kruth J, Leu M, Levy G, Rosen D, Beese A, Clare A (2017) CIRP Ann 66(2):659-681. https://doi.org/10.1016/j.cirp.2017.05.009.

8. Li N, Huang S, Zhang G, Qin R, Liu W, Xiong H, Shi G, Blackburn J (2019) Progress in additive manufacturing on new materials: A review. J Mater Sci Technol 35(2):242-269. https://doi.org/10.1016/j.jmst.2018.09.002.

9. Mittal S, Khan M, Romero D, Wuest T (2017) Smart manufacturing: Characteristics, technologies and enabling factors. Journal of Engineering Manufacture 233(5):1342-1361. https://doi.org/10.1177/ 0954405417736547.

10. Dilberoglu U, Gharehpapagh B, Yaman U, Dolen M (2017) The Role of Additive Manufacturing in the Era of Industry 4.0. Procedia Manuf 11:545-554. https://doi.org/10.1016/j.promfg.2017.07.148.

11. Schneider H-J, Kato K, Strongin R.M. (2007) Chemomechanical Polymers as Sensors and Actuators for Biological and Medicinal Applications. J Sens 7(8):1578-1611. https://doi.org/10.3390/s7081578.

12. Bar-Cohen Y, Zhang Q (2008) Electroactive Polymer Actuators and Sensors. MRS Bull 33(3):173-181. https://doi.org/10.1557/mrs2008.42.

13. Wang T, Farajollahi M, Choi YS, Lin I-T, Marshall JE, Thompson NM, Kar-Narayan S, Madden JDW, Smoukov SK (2016) Electroactive polymers for sensing. Interface Focus 6:20160026. https://doi.org/10.1098/ rsfs.2016.0026. 
14. Blackwood G, Ealey M (1993) Electrostrictive behavior in lead magnesium niobate $(\mathrm{PMN})$ actuators. I. Materials perspective. Smart Mater Struct 2(2):124-133. https://doi.org/10.1088/0964-1726/2/2/008.

15. Kumar P, Singh S, Thakur O, Prakash C, Goel T (2004) Study of Lead Magnesium Niobate-Lead Titanate Ceramics for Piezo-Actuator Applications. Jpn J Appl Phys 43(4A):1501-1506. https://doi.org/10.1143/jjap.43.1501.

16. Burcsu E, Ravichandran G, Bhattacharya K (2004) Large electrostrictive actuation of barium titanate single crystals. J Mech Phys Solids, 52(4):823-846. https://doi.org/10.1016/j.jmps.2003.08.001.

17. Baraskar B, Kambale R, James A, Mahesh M, Ramana C, Kolekar Y (2017) Ferroelectric, piezoelectric and electrostrictive properties of Sn4+-modified $\mathrm{Ba} 0.7 \mathrm{Ca} 0.3 \mathrm{TiO} 3$ lead-free electroceramics. J Am Ceram Soc 100(12):5755-5765. https://doi.org/10.1111/jace.15073.

18. Nan C, Bichurin M.I, Dong S, Viehland D, Srinivasan G (2008) Multiferroic magnetoelectric composites: Historical perspective, status, and future directions. J Appl Phys 103:031101. https://doi.org/10.1063/1.2836410.

19. Olabi AG, Grunwald A (2008) Design and application of magnetostrictive materials. Mater Des 29(2):469-483. https://doi.org/10.1016/j. matdes.2006.12.016.

20. Priya S, Islam R, Dong S, Viehland D (2007) Recent advancements in magnetoelectric particulate and laminate composites. J Electroceram 19(1):147-164. https://doi.org/10.1007/s10832-007-9042-5.

21. Rahman M, Ahmed M, Nawaz M, Molina G, Rahman A (2017) Experimental Investigation of Photostrictive Materials for MEMS Application. OALib Journal 4:e3856. https://doi.org/10.4236/oalib.1103856.

22. Sun D, Tong L (2007) Modeling of wireless remote shape control for beams using nonlinear photostrictive actuators. Int J Solids Struct 44(2):672-684. https://doi.org/10.1016/j.ijsolstr.2006.05.013.

23. Mohd Jani J, Leary M, Subic A, Gibson M (2014) A review of shape memory alloy research, applications and opportunities. Mater Des 1980-2015 56:1078-1113. https://doi.org/10.1016/j.matdes.2013.11.084.

24. Mishnaevsky L, Levashov E, Valiev R, Segurado J, Sabirov I, Enikeev N, Prokoshkin S, Solov'yov A, Korotitskiy A, Gutmanas E, Gotman I, Rabkin E, Psakh'e S, Dluhoš L, Seefeldt M, Smolin A (2014) Nanostructured titaniumbased materials for medical implants: Modeling and development. Mater Sci Eng R Rep 81:1-19. https://doi.org/10.1016/j.mser.2014.04.002.

25. Chiodo J, Jones $\mathrm{N}$ (2012) Smart materials use in active disassembly. Assembly Autom 32(1):8-24. https://doi.org/10.1108/01445151211198683.

26. Chiodo J, Jones N, Billett E (2002) WITHDRAWN: Shape memory alloy actuators for active disassembly using 'smart' materials of consumer electronic products. Mater Des https://doi.org/10.1016/s0261-3069(02)00016-x. 
27. Fu Y, Huang W, Luo J, Lu H (2015) Polyurethane shape-memory polymers for biomedical applications. In: L'Hocine Y (ed) Shape Memory Polymers for Biomedical Applications. Woodhead Publishing, Cambridge, p 167-195. https://doi.org/10.1016/B978-0-85709-698-2.00009-X.

28. Lendlein A, Langer R (2002) Biodegradable, elastic shape-memory polymers for potential biomedical applications. Science, 296(5573):1673-1676. https://doi.org/10.1038/news020422-18.

29. Tobushi H, Hayashi S, Hoshio K, Ejiri Y (2008) Shape recovery and irrecoverable strain control in polyurethane shape-memory polymer. Sci Technol Adv Mat 9(1):015009. https://doi.org/10.1088/1468-6996/9/1/015009.

30. Santo L, Quadrini F, Bellisario D, Iorio L (2019) Applications of ShapeMemory Polymers, and Their Blends and Composites. In: Parameswaranpillai J, Siengchin S, George J, Jose S (ed) Shape Memory Polymers, Blends and Composites. Advanced Structured Materials vol 115. Springer, Singapore, p 311-329. https://doi.org/10.1007/978-981-13-8574-2_13.

31. Kakeshita T, Ullakko K (2002) Giant magnetostriction in ferromagnetic shape-memory alloys. MRS Bull 27(2):105-109. https://doi.org/10.1557/ mrs2002.45.

32. Sánchez-Alarcos V, Recarte V, Pérez-Landazábal JI, González MA, Rodríguez-Velamazán JA (2009) Effect of Mn addition on the structural and magnetic properties of Fe-Pd ferromagnetic shape memory alloys. Acta Mater 57(14):4224-4232. https://doi.org/10.4028/www.scientific.net/ MSF.635.103.

33. Ullakko K, Wendell L, Smith A, Müllner P, Hampikian G (2012) A magnetic shape memory micropump: Contact-free, and compatible with PCR and human DNA profiling. Smart Mater Struct 21:11. https://doi. org/10.1088/0964-1726/21/11/115020.

34. Smith AR, Tellinen J, Ullakko K (2014) Rapid actuation and response of $\mathrm{Ni}-\mathrm{Mn}-\mathrm{Ga}$ to magnetic-field-induced stress. Acta Mater 80:373-379. https://doi.org/10.1016/j.actamat.2014.06.054.

35. Saren A, Musiienko D, Smith A, Tellinen J, Ullakko K (2015) Modeling and design of a vibration energy harvester using the magnetic shape memory effect. Smart Mater Struct 24(9):095002. https://doi.org/10.1088/09641726/24/9/095002.

36. Büsgen T, Feydt J, Hassdorf R, Thienhaus S, Moske M, Boese M, Zayak A, Entel P (2004) Ab initio calculations of structure and lattice dynamics in Ni-Mn-Al shape memory alloys. Phys. Rev B 70(1):014111-1-014111-8. https://doi.org/10.1103/PhysRevB.70.014111.

37. Bruno NM, Ciocanel C, Feigenbaum HP, Waldauer A (2012) A theoretical and experimental investigation of power harvesting using the NiMnGa martensite reorientation mechanism. Smart Mater Struct 21:9 https://doi. org/10.1088/0964-1726/21/9/094018. 
38. Ullakko K (1996) Magnetically controlled shape memory alloys: A new class of actuator materials. J Mater Eng Perform 5(3):405-409. https://doi. org/10.1007/BF02649344.

39. Ortega N, Kumar A, Scott J.F., Katiyar R.S. (2015) Multifunctional magnetoelectric materials for device applications. J Condens Matter Phys 27:50. https://doi.org/10.1088/0953-8984/27/50/504002.

40. Ma J, Hu J, Li Z and Nan C (2011) Recent Progress in Multiferroic Magnetoelectric Composites: from Bulk to Thin Films. Adv Mater 23(9):1062-1087. https://doi.org/10.1002/adma.201003636.

41. Meier QN, Fechner M, Nozaki T, Sahashi M, Salman Z, Prokscha T, Suter A, Schoenherr P, Lilienblum M, Borisov P, Dzyaloshinskii IE, Fiebig M, Luetkens H, Spaldin NA (2019) Search for the Magnetic Monopole at a Magnetoelectric Surface. Phys Rev X 9(1):011011. https://doi. org/10.1103/PhysRevX.9.011011.

42. Yokota T, Ichikawa K, Gomi M (2013) Epitaxial growth and magnetoelectric properties of magnetoelectric multilayers: Cr2o3/linbo3/cr2o 3 thin films. e-J Surf Sci Nanotech 11:89-92. https://doi.org/10.1380/ejssnt.2013.89.

43. Ce Wen Nan, Li M, Huang JH (2001) Calculations of giant magnetoelectric effects in ferroic composites of rare-earth-iron alloys and ferroelectric polymers. Phys. Rev B 63(14):1444151-1444159. https://doi.org/10.1103/ PhysRevB.63.144415.

44. Kamenetskii EO, Sigalov M, Shavit R (2008) Magnetoelectric effect for novel microwave device applications. In: Proceedings of IEEE Convention of Electrical and Electronics Engineers in Israel, p 599. https://doi. org/10.1109/EEEI.2008.4736601.

45. Yoo I, Ahn C, Cho K (2018) 15-Mode piezoelectric composite and its application in a magnetoelectric laminate structure. J Alloys Compd 767:61-67. https://doi.org/10.1016/j.jallcom.2018.07.084.

46. Fuentes-Cobas LE, Matutes-Aquino JA, Botello-Zubiate ME, GonzálezVázquez A, Fuentes-Montero ME, Chateigner D (2015) Advances in Magnetoelectric Materials and Their Application, Handbook of Magnetic Materials 24:237-322. https://doi.org/10.1016/bs.hmm.2015.10.001.

47. Pizzini S (2012) Advanced Silicon Materials for Photovoltaic Applications. John Wiley \& Sons, Chichester.

48. Czaban JA, Thompson DA, LaPierre RR (2009) GaAs core-shell nanowires for photovoltaic applications. Nano Lett 9(1):148-154. https://doi. org/10.1021/nl802700u.

49. Scheer R, Schock H (2011) Chalcogenide Photovoltaics: Physics, Technologies, and Thin Film Devices. Wiley-VCH, Singapore. 
50. Qu YH, Cong DY, Sun XM, Nie ZH, Gui WY, Li RG, Ren Y, Wang YD (2017) Giant and reversible room-temperature magnetocaloric effect in Ti-doped Ni-Co-Mn-Sn magnetic shape memory alloys. Acta Mater 134:236-248. https://doi.org/10.1016/j.actamat.2017.06.010.

51. Cheng J, Tang J, Zhang A, Meng X, Chu J (2000) Sol-gel-derived pyroelectric barium strontium titanate thin films for infrared detector applications. Appl Phys A-Mater 71(6):667-670. https://doi.org/10.1080/ 00150190108016271.

52. Grudkowski TW, Montress GK, Gilden M, Black JF (1981) Integrated Circuit Compatible Surface Acoustic Wave Devices on Gallium Arsenide. IEEE Trans. Microw. Theory Tech 29(12):1348-1356. https://doi. org/10.1109/TMTT.1981.1130564.

53. Mescher M, Abe T, Brunett B, Metla H, Schlesinger TE, Reed M (1995) Piezoelectric lead-zirconate-titanate actuator films for microelectromechanical systems applications. In: Proceedings of the IEEE Micro Electro Mechanical Systems, p 261. https://doi.org/10.1109/MEMSYS.1995.472537.

54. Parton E, Bartic C, Campitelli A (2004) Micro-system platforms/new materials for biosensor applications. Solid State Technol 47(4):s1-s2.

55. Zhao Y, Fang X, Jiang Z, Zhao L (2010) An ultra-high pressure sensor based on SOI piezoresistive material. Journal of Mech Sci Technol 24(8):1655-1660. https://doi.org/10.1007/s12206-010-0515-0.

56. Tschan T, de Rooij N, Bezinge A (1992) Damping of piezoresistive silicon accelerometers. Sensor Actuat A-Phys, 32(1-3):375-379. https://doi. org/10.1016/0924-4247(92)80015-U.

57. Jovanovic V, Ghamaty S, Bass JC (2012) New thermoelectric materials and applications. In: Proceedings of InterSociety Conference on Thermal and Thermomechanical Phenomena in Electronic Systems, p 1159. https://doi. org/10.1109/ITHERM.2012.6231554.

58. Yang J, Stabler FR (2009) Automotive applications of thermoelectric materials. J Electron Mater 38(7):1245-1251. https://doi.org/10.1007/ s11664-009-0680-z.

59. Kuo C, Wu T, Fan S (2018) Applications of Poly(indole-6-carboxylic acidco-2,2'-bithiophene) Films in High-Contrast Electrochromic Devices. Coatings 8(3):102. https://doi.org/10.3390/coatings8030102.

60. Lin K, Zhang S, Liu H, Zhao Y, Wang Z, Xu J (2015) Effects on the electrochemical and electrochromic properties of 3 linked polythiophene derivative by the introduction of polyacrylate. Int J Electrochem Sci 10(9):7720-7731.

61. Fabre-Francke I, Aubert P, Alfonsi S, Vidal F, Sauques L, Chevrot C (2012) Electropolymerization of 3,4-ethylenedioxythiophene within an insulating nitrile butadiene rubber network: Application to electroreflective surfaces and devices. Sol Energy Mater Sol Cells 99:109-115. https://doi. org/10.1016/j.solmat.2011.07.004. 
62. Granqvist C (2014) Electrochromics for smart windows: Oxide-based thin films and devices. Thin Solid Films 564:1-38. https://doi.org/10.1016/j. tsf.2014.02.002.

63. Tajima K, Yamada Y, Bao S, Okada M, Yoshimura K (2008) Flexible all-solidstate switchable mirror on plastic sheet. Appl Phys Lett 92(4):041912. https://doi.org/10.1063/1.2839298.

64. Smith II RD, Benson DK, Maroef I, Olson DL, Wildeman TR (2001) The determination of hydrogen distribution in high-strength steel weldments. Part 2: Opto-electronic diffusible hydrogen sensor. Weld J 80(5):122s-125s.

65. Benson, D.K., Tracy, C.E., Hishmeh, G.A., Ciszek, P.E., Lee, S. \& Haberman, D.P. (1999). In: Proceedings of SPIE-The International Society for Optical Engineering 3535, p 185-202. https://doi.org/10.1117/12.337465.

66. Shirota Y, Utsumi H, Ujike T, Yoshikawa S, Moriwaki K, Nagahama D, Nakano H (2003) Photochromic amorphous molecular materials and their applications. Opt Mater 21(1-3):249-254. https://doi.org/10.1016/ S0925-3467(02)00145-3.

67. Tangso KJ, Fong W-K, Darwish T, Kirby N, Boyd BJ, Hanley TL (2013) Novel spiropyran amphiphiles and their application as light-responsive liquid crystalline components. J Phys Chem B 117(35):10203-10210. https:// doi.org/10.1021/jp403840m.

68. Levy D (1997) Recent applications of photochromic sol-gel materials. Mol Cryst Liq Cryst Sci Tech 297-298:31-39. https://doi.org/10.1080/ 10587259708036100.

69. Yang Y, Psaltis D, Luennemann M, Berben D, Hartwig U, Buse K (2003) Photorefractive properties of lithium niobate crystals doped with manganese. J Opt Soc Am B 20(7):1491. https://doi.org/10.1364/josab.20.001491.

70. Ducharme S, Feinberg J (1986) Altering the photorefractive properties of BaTiO_3 by reduction and oxidation at $650^{\circ} \mathrm{C}$. J Opt Soc Am B 3(2):283. https://doi.org/10.1364/josab.3.000283.

71. Li Y, Ji S, Gao Y, Luo H, Kanehira M (2013) Core-shell VO2 @TiO2 nanorods that combine thermochromic and photocatalytic properties for application as energy-saving smart coatings. Sci Rep 3:1370 https://doi. org/10.1038/srep01370.

72. Hao Q, Li W, Xu H, Wang J, Yin Y, Wang H, Ma L, Ma F, Jiang X, Schmidt OG, Chu PK (2018) VO 2 /TiN Plasmonic Thermochromic Smart Coatings for Room-Temperature Applications. Adv Mater 30(10):1705421. https:// doi.org/10.1002/adma.201705421.

73. Pucci A, Ruggeri G (2011) Mechanochromic polymer blends. J Mater Chem 21(23):8282. https://doi.org/10.1039/C0JM03653F.

74. Jiang Y (2014) An outlook review: Mechanochromic materials and their potential for biological and healthcare applications. Mater Sci Eng: C 45:682-689. https://doi.org/10.1016/j.msec.2014.08.027. 
75. Gao F, Xiong Z, Xue H, Liu Y (2009) Improved performance of strontium aluminate luminous coating on the ceramic surface. J Phys 152:012082. https://doi.org/10.1088/1742-6596/152/1/012082.

76. Giuliani F, Autelitano F (2014) Photoluminescent road surface dressing: A first laboratory experimental investigation. Mater Tech 102(6-7):603. https://doi.org/10.1051/mattech/2014030.

77. Azorin J (2014) Preparation methods of thermoluminescent materials for dosimetric applications: An overview. Appl Radiat Isot 83:187-191. https:// doi.org/10.1016/j.apradiso.2013.04.031.

78. Tang W, Cameron DC (1996) Electroluminescent zinc sulphide devices produced by sol-gel processing. Thin Solid Films 280(1-2):221-226. https:// doi.org/10.1016/0040-6090(95)08198-4.

79. Smet P, Moreels I, Hens Z, Poelman D (2010) Luminescence in Sulfides: A Rich History and a Bright Future. Mater 3(4):2834-2883. https://doi. org/10.3390/ma3042834.

80. Feng A, Smet P (2018) A Review of Mechanoluminescence in Inorganic Solids: Compounds, Mechanisms, Models and Applications. Mater 11(4):484. https://doi.org/10.3390/mal1040484.

81. Di B, Chen Y (2018) Recent progress in organic mechanoluminescent materials. Chin Chem Lett 29(2):245-251. https://doi.org/10.1016/j. cclet.2017.08.043.

82. Ding J, Li W, SZ Shen (2011) Research and Applications of Shear Thickening Fluids. Recent Pat Mater Sci 4(1):43-49. https://doi.org/10.217 4/1874464811104010043.

83. Gürgen S, Kushan M, Li W (2017) Shear thickening fluids in protective applications: Areview. Prog Polym Sci 75:48-72. https://doi.org/10.1016/j. progpolymsci.2017.07.003.

84. Hao T (2002) Electrorheological suspensions. Adv Colloid Interface Sci 97(1-3):1-35. https://doi.org/10.1016/S0001-8686(01)00045-8.

85. Agafonov, A. and Zakharov, A. (2010) Electrorheological fluids. Russ J Gen Chem 80:567-575. https://doi.org/10.1134/S1070363210030382.

86. de Vicente J, Klingenberg D, Hidalgo-Alvarez R (2011) Magnetorheological fluids: a review. Soft Matter 7(8):3701. https://doi.org/10.1039/ COSM01221A.

87. Spaggiari A (2012) Properties and applications of Magnetorheological fluids. Frattura ed Integrità Strutturale 7(23):48-61. https://doi.org/10.3221/ IGF-ESIS.23.06

88. Kostamo E, Kostamo J, Kajaste J, Pietola M (2012) Magnetorheological valve in servo applications. J Intel Mater Syst Str 23(9):1001-1010. https:// doi.org/10.1177/1045389X12436732. 
89. Krishna B, Bose S, Bandyopadhyay A (2007) Laser Processing of Net-Shape NiTi Shape Memory Alloy. Metallurgical and Materials Transactions A 38(5):1096-1103. https://doi.org/10.1007/s11661-007-9127-4.

90. Marattukalam J, Singh A, Datta S, Das M, Balla V, Bontha S, Kalpathy S (2015) Microstructure and corrosion behavior of laser processed NiTi alloy. Mater Sci Eng C 57:309-313. https://doi.org/10.1016/j. msec.2015.07.067.

91. Hamilton R, Palmer T, Bimber B (2015) Spatial characterization of the thermal-induced phase transformation throughout as-deposited additive manufactured NiTi bulk builds. Scr Mater 101:56-59. https://doi.org/10.1016/j. scriptamat.2015.01.018.

92. Hamilton R, Bimber B, Palmer T (2018) Correlating microstructure and superelasticity of directed energy deposition additive manufactured Ni-rich NiTi alloys. J Alloy Compd 739:712-722. https://doi.org/10.1016/j. jallcom.2017.12.270.

93. Bimber B, Hamilton R, Keist J, Palmer T (2016) Anisotropic microstructure and superelasticity of additive manufactured NiTi alloy bulk builds using laser directed energy deposition. Mater Sci Eng A 674:125-134. https://doi. org/10.1016/j.msea.2016.07.059.

94. Hamilton R, Bimber B, Taheri AM, Elahinia M (2017) Multi-scale shape memory effect recovery in NiTi alloys additive manufactured by selective laser melting and laser directed energy deposition. J Mater Process Technol 250:55-64. https://doi.org/10.1016/j.jmatprotec.2017.06.027.

95. Shiva S, Palani I, Mishra S, Paul C, Kukreja L (2015) Investigations on the influence of composition in the development of Ni-Ti shape memory alloy using laser based additive manufacturing. Opt Laser Technol 69:44-51. https://doi.org/10.1016/j.optlastec.2014.12.014.

96. Baran A, Polanski M (2018) Microstructure and properties of LENS (laser engineered net shaping) manufactured $\mathrm{Ni}$-Ti shape memory alloy. J Alloy Compd 750:863-870. https://doi.org/10.1016/j.jallcom.2018.03.400.

97. Wang C, Tan X, Du Z, Chandra S, Sun Z, Lim C, Tor S, Lim C, Wong C (2019) Additive manufacturing of NiTi shape memory alloys using premixed powders. J Mater Process Technol 271:152-161. https://doi. org/10.1016/j.jmatprotec.2019.03.025.

98. Shishkovsky I, Yadroitsev I, Smurov I (2012) Direct Selective Laser Melting of Nitinol Powder. Phys Procedia 39:447-454. https://doi.org/10.1016/j. phpro.2012.10.060.

99. Walker J, Haberland C, Taheri AM, Karaca H, Dean D, Elahinia M (2016) Process development and characterization of additively manufactured nickeltitanium shape memory parts. J Intel Mat Syst Str 27(19):2653-2660. https://doi.org/10.1177/1045389X16635848 
100. Speirs M, Van Hooreweder B, Van Humbeeck J, Kruth J (2017) Fatigue behaviour of NiTi shape memory alloy scaffolds produced by SLM, a unit cell design comparison. J Mech Behav Biomed Mater 70:53-59. https://doi. org/10.1016/j.jmbbm.2017.01.016.

101. Walker J, Elahinia M, Haberland C (2013) An Investigation of Process Parameters on Selective Laser Melting of Nitinol. In: Proceedings of the ASME 2013 Conference on Smart Materials, Adaptive Structures and Intelligent Systems Vol 1, V001T01A007. https://doi.org/10.1115/ SMASIS2013-3074.

102. Bormann T, Schumacher R, Müller B, Mertmann M, de Wild M (2012) Tailoring Selective Laser Melting Process Parameters for NiTi Implants. J Mater Eng Perform 21(12):2519-2524. https://doi.org/10.1007/ s11665-012-0318-9.

103. Jahadakbar A, Shayesteh MN, Amerinatanzi A, Dean D, Karaca H, Elahinia M (2016) Finite Element Simulation and Additive Manufacturing of Stiffness-Matched NiTi Fixation Hardware for Mandibular Reconstruction Surgery. Bioengineering 3(4):36. https://doi.org/10.3390/ bioengineering 3040036 .

104. Saedi S, Turabi A, Taheri AM, Haberland C, Karaca H, Elahinia M (2016) The influence of heat treatment on the thermomechanical response of Ni-rich NiTi alloys manufactured by selective laser melting. J Alloy Compd 677:204-210. https://doi.org/10.1016/j.jallcom.2016.03.161.

105. Saedi S, Turabi A, Andani M, Haberland C, Elahinia M, Karaca H (2016) Thermomechanical characterization of Ni-rich NiTi fabricated by selective laser melting. Smart Mater Struct 25(3):035005. https://doi. org/10.1088/0964-1726/25/3/035005.

106. Saedi S, Turabi A, Andani M, Moghaddam N, Elahinia M, Karaca H (2017) Texture, aging, and superelasticity of selective laser melting fabricated $\mathrm{Ni}$-rich NiTi alloys. Mater Sci Eng A 686:1-10. https://doi.org/10.1016/j. msea.2017.01.008.

107. Saedi S, Shayesteh AN, Amerinatanzi A, Elahinia M, Karaca H (2018) On the effects of selective laser melting process parameters on microstructure and thermomechanical response of Ni-rich NiTi. Acta Mater 144:552-560. https://doi.org/10.1016/j.actamat.2017.10.072.

108. Shayesteh MN, Saedi S, Amerinatanzi A, Hinojos A, Ramazani A, Kundin J, Mills M, Karaca H, Elahinia M (2019) Achieving superelasticity in additively manufactured NiTi in compression without post-process heat treatment. Sci Rep 9(1):41. https://doi.org/10.1038/s41598-018-36641-4.

109. Li S, Hassanin H, Attallah M, Adkins N, Essa K (2016) The development of TiNi-based negative Poisson's ratio structure using selective laser melting. Acta Mater 105:75-83. https://doi.org/10.1016/j.actamat.2015.12.017. 
110. Taheri AM, Saedi S, Turabi A, Karamooz M, Haberland C, Karaca H, Elahinia M (2017) Mechanical and shape memory properties of porous $\mathrm{Ni}$ 50.1 Ti 49.9 alloys manufactured by selective laser melting. J Mech Behav Biomed 68:224-231. https://doi.org/10.1016/j.jmbbm.2017.01.047.

111. Shayesteh MN, Saghaian S, Amerinatanzi A, Ibrahim H, Li P, Toker G, Karaca H, Elahinia M (2018) Anisotropic tensile and actuation properties of NiTi fabricated with selective laser melting. Mat Sci Eng A 724:220-230. https://doi.org/10.1016/j.msea.2018.03.072.

112. Taheri AM, Haberland C, Walker J, Karamooz M, Sadi TA, Saedi S, Rahmanian R, Karaca H, Dean D, Kadkhodaei M, Elahinia M (2016) Achieving biocompatible stiffness in NiTi through additive manufacturing. J Intel Mat Syst Str 27(19):2661-2671. https://doi.org/10.117 7/1045389X16641199.

113. Elahinia M, Shayesteh MN, Amerinatanzi A, Saedi S, Toker G, Karaca H, Bigelow G, Benafan O (2018) Additive manufacturing of NiTiHf high temperature shape memory alloy. Scr Mater 145:90-94. https://doi. org/10.1016/j.scriptamat.2017.10.016

114. Sam J, Franco B, Ma J, Karaman I, Elwany A, Mabe J (2018) Tensile actuation response of additively manufactured nickel-titanium shape memory alloys. Scr Mater 146:164-168. https://doi.org/10.1016/j.scriptamat.2017.11.013.

115. Dadbakhsh S, Speirs M, Van Humbeeck J, Kruth J (2016) Laser additive manufacturing of bulk and porous shape-memory NiTi alloys: From processes to potential biomedical applications. MRS Bull 41(10):765-774. https://doi.org/10.1557/mrs.2016.209.

116. Dadbakhsh S, Vrancken B, Kruth J, Luyten J, Van Humbeeck J (2016) Texture and anisotropy in selective laser melting of NiTi alloy. Mat Sci Eng A 650:225-232. https://doi.org/10.1016/j.msea.2015.10.032.

117. Khoo Z, An J, Chua C, Shen Y, Kuo C, Liu Y (2018) Effect of Heat Treatment on Repetitively Scanned SLM NiTi Shape Memory Alloy. Materials 12(1):77. https://doi.org/10.3390/mal2010077.

118. Speirs M, Wang X, Van BS, Ahadi A, Dadbakhsh S, Kruth J, Van Humbeeck J (2016) On the Transformation Behavior of NiTi Shape-Memory Alloy Produced by SLM. Shap. Mem. Superelasticity 2(4):310-316. https://doi. org/10.1007/s40830-016-0083-y.

119. Hagemann R, Noelke C, Rau T, Kaierle S, Overmeyer L, Wesling V, Wolkers W (2015) Design, processing, and characterization of nickel titanium microactuators for medical implants. J Laser Appl 27(S2):S29203. https://doi. org/10.2351/1.4906381.

120. Khademzadeh S, Parvin N, Bariani P, Mazzucato F (2015) Effects of micro laser sintering process parameters on quality of nickel-titanium single tracks and thin walls. Met and Mater Int 21(6):1081-1090. https://doi. org/10.1007/s12540-015-5304-y. 
121. Hayat M, Chen G, Liu N, Khan S, Tang H, Cao P (2018) Physical and Tensile Properties of NiTi Alloy by Selective Electron Beam Melting. Key Eng Mater 770:148-154. https://doi.org/10.4028/www.scientific.net/ KEM.770.148.

122. Zhou Q, Hayat M, Chen G, Cai S, Qu X, Tang H, Cao P (2019) Selective electron beam melting of NiTi: Microstructure, phase transformation and mechanical properties. Mat Sci Eng A 744:290-298. https://doi. org/10.1016/j.msea.2018.12.023.

123. Lu B, Cui X, Liu E, Feng X, Dong M, Li Y, Wang H, Jin G (2018) Influence of microstructure on phase transformation behavior and mechanical properties of plasma arc deposited shape memory alloy. Mat Sci Eng A 736:130-136. https://doi.org/10.1016/j.msea.2018.08.098.

124. Lu B, Cui X, Feng X, Dong M, Li Y, Cai Z, Wang H, Jin G (2018) Direct rapid prototyping of shape memory alloy with linear superelasticity via plasma arc deposition. Vacuum 157:65-68. https://doi.org/10.1016/j. vacuum.2018.08.028.

125. Wang J, Pan Z, Yang G, Han J, Chen X, Li H (2019) Location dependence of microstructure, phase transformation temperature and mechanical properties on Ni-rich NiTi alloy fabricated by wire arc additive manufacturing. Mat Sci Eng A 749:218-222. https://doi.org/10.1016/j.msea.2019.02.029.

126. Reyes DG, Walczak M, Ramos ME, Ramos-Grez J (2017) Towards direct metal laser fabrication of Cu-based shape memory alloys. Rapid Prototyp J 23(2):329-336. https://doi.org/10.1108/RPJ-02-2016-0017.

127. Gargarella P, Kiminami C, Mazzer E, Cava R, Basilio L, Bolfarini C, Botta W, Eckert J, Gustmann T, Pauly S (2015) Phase Formation, Thermal Stability and Mechanical Properties of a Cu-Al-Ni-Mn Shape Memory Alloy Prepared by Selective Laser Melting. Mater Res 18(2):35-38. https://doi. org/10.1590/1516-1439.338914.

128. Gustmann T, Neves A, Kühn U, Gargarella P, Kiminami C, Bolfarini C, Eckert J, Pauly S (2016) Influence of processing parameters on the fabrication of a Cu-Al-Ni-Mn shape-memory alloy by selective laser melting. Addit Manuf 11:23-31. https://doi.org/10.1016/j.addma.2016.04.003

129. Gustmann T, Schwab H, Kühn U, Pauly S (2018) Selective laser remelting of an additively manufactured $\mathrm{Cu}-\mathrm{Al}-\mathrm{Ni}-\mathrm{Mn}$ shape-memory alloy. Mater Des 153:129-138. https://doi.org/10.1016/j.matdes.2018.05.010.

130. Gustmann T, dos Santos J, Gargarella P, Kühn U, Van Humbeeck J, Pauly S (2016) Properties of Cu-Based Shape-Memory Alloys Prepared by Selective Laser Melting. Shap. Mem. Superelasticity 3(1):24-36. https://doi. org/10.1007/s40830-016-0088-6.

131. Tian J, Zhu W, Wei Q, Wen S, Li S, Song B, Shi Y (2019) Process optimization, microstructures and mechanical properties of a $\mathrm{Cu}$-based shape memory alloy fabricated by selective laser melting. J Alloy Compd 785:754-764. https://doi.org/10.1016/j.jallcom.2019.01.153. 
132. Niendorf T, Brenne F, Krooß P, Vollmer M, Günther J, Schwarze D, Biermann H (2016) Microstructural Evolution and Functional Properties of Fe-Mn-Al-Ni Shape Memory Alloy Processed by Selective Laser Melting. Metall Mater Trans A 47(6):2569-2573. https://doi.org/10.1007/ s11661-016-3412-z.

133. Taylor S, Shah R, Dunand D (2018) Ni-Mn-Ga micro-trusses via sintering of 3D-printed inks containing elemental powders. Acta Mater 143:20-29. https://doi.org/10.1016/j.actamat.2017.10.002.

134. Taylor S, Shah R Dunand D (2019) Microstructure and porosity evolution during sintering of $\mathrm{Ni}-\mathrm{Mn}-\mathrm{Ga}$ wires printed from inks containing elemental powders. Intermetallics, 104:113-123. https://doi.org/10.1016/j. intermet.2018.10.024.

135. Caputo M, Solomon C, Nguyen P, Berkowitz A (2016) Electron Microscopy Investigation of Binder Saturation and Microstructural Defects in Functional Parts Made by Additive Manufacturing. Microsc Microanal 22(S3):1770-1771. https://doi.org/10.1017/S1431927616009697.

136. Caputo M, Berkowitz A, Armstrong A, Müllner P, Solomon C (2018) 4D printing of net shape parts made from Ni-Mn-Ga magnetic shape-memory alloys. Addit Manuf 21:579-588. https://doi.org/10.1016/j. addma.2018.03.028.

137. Caputo M, Solomon C (2017) A facile method for producing porous parts with complex geometries from ferromagnetic Ni-Mn-Ga shape memory alloys. Mater Lett 200:87-89. https://doi.org/10.1016/j. matlet.2017.04.112.

138. Mostafaei A, Kimes K, Stevens E, Toman J, Krimer Y, Ullakko K, Chmielus M (2017) Microstructural evolution and magnetic properties of binder jet additive manufactured Ni-Mn-Ga magnetic shape memory alloy foam. Acta Mater 131:482-490. https://doi.org/10.1016/j.actamat.2017.04.010.

139. Mostafaei A, Rodriguez De Vecchis P, Stevens E, Chmielus M (2018) Sintering regimes and resulting microstructure and properties of binder jet 3D printed Ni-Mn-Ga magnetic shape memory alloys. Acta Mater 154:355-364. https://doi.org/10.1016/j.actamat.2018.05.047.

140. Caputo M, Solomon C (2017) Microstructure and Chemical Composition Analysis of Additive Manufactured Ni-Mn-Ga Parts Sintered in Different Conditions. Microsc Microanal 23(S1):2078-2079. https://doi. org/10.1017/S1431927617011059.

141. Toman J, Müllner P, Chmielus M (2018) Properties of as-deposited and heat-treated Ni-Mn-Ga magnetic shape memory alloy processed by directed energy deposition. J Alloy Compd 752:455-463. https://doi. org/10.1016/j.jallcom.2018.04.059.

142. Ullakko K, Laitinen V, Saren A, Sozinov A, Musiienko D, Chmielus M, Salminen A (2018) Ni-Mn-Ga actuating elements manufactured using 3D 
printing. Paper presented at the 11th European Symposium on Martensitic Transformations, Metz, 27-31 August 2018.

143. Laitinen V, Sozinov A, Saren A, Salminen A, Ullakko K (2019) Laser powder bed fusion of Ni-Mn-Ga magnetic shape memory alloy. Addit Manuf 30C: 100891. https://doi.org/10.1016/j.addma.2019.100891.

144. Nilsén F, Ituarte I, Salmi M, Partanen J, Hannula S (2019) Effect of process parameters on non-modulated Ni-Mn-Ga alloy manufactured using powder bed fusion. Addit Manuf 28:464-474. https://doi.org/10.1016/j. addma.2019.05.029.

145. Laitinen V, Salminen A, Ullakko K (2019) First investigation on processing parameters for laser powder bed fusion of $\mathrm{Ni}-\mathrm{Mn}$-Ga magnetic shape memory alloy. J Laser Appl 31(2):022303. https://doi.org/10.2351/1.5096108.

146. Laitinen V, Sozinov A, Saren A, Ullakko K (2019) Laser based 4D printing of Ni-Mn-Ga MSM alloy. In: Book of abstracts of 6th International Conference on Ferromagnetic Shape Memory Alloys p 156-157. ISBN 978-80-905962-9-0.

147. Stevens E, Toman J, Kimes K, Chernenko V, Wojcik A, Maziarz W, Chmielus M (2016) Microstructural Evaluation of Magnetocaloric Ni-Co-Mn-Sn Produced by Directed Energy Deposition. Microsc Microanal 22(S3):1774-1775. https://doi.org/10.1017/s1431927616009715.

148. Stevens E, Kimes K, Chernenko V, Wojcik A, Maziarz W, Toman J, Chmielus M (2017). Characterization of Direct Laser Deposited Magnetocaloric Ni-CoMn-Sn. In: Proceedings of Materials Science and Technology, p 430-432. https://doi.org/10.7449/2017mst/2017/mst_2017_430_432.

149. Stevens E, Kimes K, Chernenko V, Lazpita P, Wojcik A, Maziarz W, Chmielus M (2018) Direct Laser Deposition and Homogenization of Ni-Co-Mn-Sn Magnetocaloric Material. Microsc Microanal 24(S1):956-957. https://doi. org/10.1017/s1431927618005275.

150. Stevens E, Salazar D, Kimes K, de Vecchis R, Chernenko V, Chmielus M (2019) Additive Manufacturing of Ni-Mn-Cu-Ga: Influence of Sintering Temperature on Magnetocaloric Effect and Microstructure. Microsc Microanal 25(S2):2578-2579. https://doi.org/10.1017/S143192761901362X.

151. Ma J, Franco B, Tapia G, Karayagiz K, Johnson L, Liu J, Arroyave R, Karaman I, Elwany A (2017) Spatial Control of Functional Response in 4D-Printed Active Metallic Structures. Sci Rep 7(1):46707. https://doi. org/10.1038/srep46707.

152. Khoo Z, Teoh J, Liu Y, Chua C, Yang S, An J, Leong K, Yeong W (2015) 3D printing of smart materials: A review on recent progresses in $4 \mathrm{D}$ printing. Virtual Phys Prototy 10(3):103-122. https://doi.org/10.1080/1745275 9.2015.1097054.

153. Leist S, Zhou J (2016) Current status of 4D printing technology and the potential of light-reactive smart materials as $4 \mathrm{D}$ printable materials. Virtual 
Phys Prototy 11(4):249-262. https://doi.org/10.1080/1745275 9.2016.1198630

154. Lee J, An J, Chua C (2017) Fundamentals and applications of 3D printing for novel materials. Appl Mater Today 7:120-133. https://doi. org/10.1016/j.apmt.2017.02.004.

155. Lee A, An J, Chua C (2017) Two-Way 4D Printing: A Review on the Reversibility of 3D-Printed Shape Memory Materials. Eng 3(5):663-674. https://doi.org/10.1016/J.ENG.2017.05.014.

156. Mitchell A, Lafont U, Hołyńska M, Semprimoschnig C (2018) Additive manufacturing - A review of 4D printing and future applications. Addit Manuf 24:606-626. https://doi.org/10.1016/j.addma.2018.10.038

157. Momeni FM. Mehdi Hassani.N S, Liu X, Ni J (2017) A review of 4D printing. Mater Des 122:42-79. https://doi.org/10.1016/j.matdes.2017.02.068.

158. Boydston A, Cao B, Nelson A, Ono R, Saha A, Schwartz J, Thrasher C (2018) Additive manufacturing with stimuli-responsive materials. J Mater Chem A 6(42):20621-20645. https://doi.org/10.1039/C8TA07716A.

159. Chang J, He J, Mao M, Zhou W, Lei Q, Li X, Li D, Chua C, Zhao X (2018) Advanced Material Strategies for Next-Generation Additive Manufacturing. Materials 11(1):166. https://doi.org/10.3390/mal1010166.

160. Kuang X, Roach D, Wu J, Hamel C, Ding Z, Wang T, Dunn M, Qi H (2018) Advances in 4D Printing: Materials and Applications. Adv Funct Mater 29(2):1805290. https://doi.org/10.1002/adfm.201805290.

161. Zhang Z, Demir K, Gu G (2019) Developments in 4D-printing: a review on current smart materials, technologies, and applications. Inter J Smart Nano Mater 10:205-224. https://doi.org/10.1080/19475411.2019.1591541.

162. Li X, Shang J, Wang Z (2017) Intelligent materials: a review of applications in 4D printing. Assembly Autom 37(2):170-185. https://doi.org/10.1108/ AA-11-2015-093.

163. Oliveira J, Correia V, Castro H, Martins P, Lanceros-Mendez S (2018) Polymer-based smart materials by printing technologies: Improving application and integration. Addit Manuf 21:269-283. https://doi.org/10.1016/j. addma.2018.03.012.

164. Sossou G, Demoly F, Belkebir H, Qi H, Gomes S, Montavon G (2019) Design for 4D printing: A voxel-based modeling and simulation of smart materials. Mater Des 175:107798. https://doi.org/10.1016/j. matdes.2019.107798.

165. Zhang Z, Demir K, Gu G (2019) Developments in 4D-printing: a review on current smart materials, technologies, and applications. International Journal of Smart and Nano Materials 10(3):205-224. https://doi.org/10.108 0/19475411.2019.1591541. 
166. Gardan J (2018) Smart materials in additive manufacturing: state of the art and trends. Virtual Phys Prototyp 14(1):1-18. https://doi.org/10.108 0/17452759.2018.1518016.

167. Shafranek R, Millik S, Smith P, Lee C, Boydston A, Nelson A (2019) Stimuliresponsive materials in additive manufacturing. Prog Polym Sci 93:36-67. https://doi.org/10.1016/j.progpolymsci.2019.03.002.

168. Yamauchi K, Ohkata I, Tsuchiya K, Miyazaki S (2011) Shape memory and superelastic alloys: applications and technologies. Woodhead Publishing, Oxford.

169. Duerig T (2012) Shape Memory Alloys. In: ASM Handbook, Volume 23Materials for medical devices. ASM International, Ohio, p 237-250.

170. Van Humbeeck J (1999) Non-medical applications of shape memory alloys. Mat Sci Eng A 273-275:134-148. https://doi.org/10.1016/ S0921-5093(99)00293-2.

171. Elahinia M, Hashemi M, Tabesh M, Bhaduri S (2012) Manufacturing and processing of NiTi implants: A review. Prog Mater Sci 57(5):911-946. https://doi.org/10.1016/j.pmatsci.2011.11.001.

172. Elahinia M, Shayesteh MN, Taheri AM, Amerinatanzi A, Bimber B, Hamilton R (2016) Fabrication of NiTi through additive manufacturing: A review. Prog Mater Sci 83:630-663. https://doi.org/10.1016/j.pmatsci.2016.08.001.

173. Van Humbeeck J (2018) Additive Manufacturing of Shape Memory Alloys. Shap. Mem. Superelasticity 4(2):309-312. https://doi.org/10.1007/ s40830-018-0174-z.

174. Wang X, Kustov S, Van Humbeeck J (2018) A Short Review on the Microstructure, Transformation Behavior and Functional Properties of NiTi Shape Memory Alloys Fabricated by Selective Laser Melting. Materials 11(9):1683. https://doi.org/10.3390/mal1091683.

175. Ullakko K, Huang J, Kantner C, O’Handley R, Kokorin V (1996) Large magnetic-field-induced strains in Ni2MnGa single crystals. Appl Phys Lett 69(13):1966-1968. https://doi.org/10.1063/1.117637.

176. Sozinov A, Lanska N, Soroka A, Zou W (2013) 12\% magnetic field-induced strain in Ni-Mn-Ga-based non-modulated martensite. Appl Phys Lett 102(2):021902. https://doi.org/10.1063/1.4775677.

177. Aaltio I, Soroka A, Ge Y, Söderberg O, Hannula S (2010) High-cycle fatigue of $10 \mathrm{M} \mathrm{Ni-Mn-Ga} \mathrm{magnetic} \mathrm{shape} \mathrm{memory} \mathrm{alloy} \mathrm{in} \mathrm{reversed} \mathrm{mechanical}$ loading. Smart Materials and Structures 19(7):075014. https://doi. org/10.1088/0964-1726/19/7/075014.

178. Smith A, Tellinen J, Ullakko K (2014) Rapid actuation and response of NiMn-Ga to magnetic-field-induced stress. Acta Mater 80:373-379. https:// doi.org/10.1016/j.actamat.2014.06.054.

179. Gaitzsch U, Pötschke M, Roth S, Rellinghaus B, Schultz L (2009) A 1\% magnetostrain in polycrystalline 5M Ni-Mn-Ga. Acta Mater 57(2):365-370. https://doi.org/10.1016/j.actamat.2008.09.017. 
180. Chmielus M, Zhang X, Witherspoon C, Dunand D, Müllner P (2009) Giant magnetic-field-induced strains in polycrystalline $\mathrm{Ni}-\mathrm{Mn}-\mathrm{Ga}$ foams. Nat Mater 8(11):863-866. https://doi.org/10.1038/nmat2527.

181. Kok Y, Tan X, Wang P, Nai M, Loh N, Liu E, Tor S (2018) Anisotropy and heterogeneity of microstructure and mechanical properties in metal additive manufacturing: A critical review. Mater Des 139:565-586. https://doi. org/10.1016/j.matdes.2017.11.021.

182. Waske A, Dutta B, Teichert N, Weise B, Shayanfar N, Becker A, Hütten A, Hickel T (2018) Coupling Phenomena in Magnetocaloric Materials. Energy Technol 6(8):1429-1447. https://doi.org/10.1002/ente.201800163.

183. Brown G (1976) Magnetic heat pumping near room temperature. J App Phys 47(8):3673-3680. https://doi.org/10.1063/1.323176

184. Lyubina J (2017) Magnetocaloric materials for energy efficient cooling. J Phys D App Phys 50(5):053002. https://doi.org/10.1088/1361$6463 / 50 / 5 / 053002$.

185. Weiss P, Piccard A (1917) Le phénomène magnétocalorique. J Phys Théor App 7(1):103-109. https://doi.org/10.1051/jphystap:019170070010300.

186. Franco V, Blázquez J, Ipus J, Law J, Moreno-Ramírez L, Conde A (2018) Prog Mater Sci 93:112-232. https://doi.org/10.1016/j.pmatsci.2017.10.005.

187. Yang Y, Tong C, Zhong J, Huang R, Tan W, Tan Z (2017) An effective thermal therapy against cancer using an E-jet 3D-printing method to prepare implantable magnetocaloric mats. J Biomed Mater Res B 106(5):1827-1841. https://doi.org/10.1002/jbm.b.33992.

188. Fähler S, Rößler U, Kastner O, Eckert J, Eggeler G, Emmerich H, Entel P, Müller S, Quandt E, Albe K (2011) Caloric Effects in Ferroic Materials: New Concepts for Cooling. Adv Eng Mater 14(1-2):10-19. https://doi. org/10.1002/adem.201100178.

189. Fähler S, Pecharsky V (2018) Caloric effects in ferroic materials. MRS Bull 43(4):264-268. https://doi.org/10.1557/mrs.2018.66.

190. Waske A, Gruner M, Gottschall T, Gutfleisch O (2018) Magnetocaloric materials for refrigeration near room temperature. MRS Bull 43(4):269-273. https://doi.org/10.1557/mrs.2018.69.

191. Lozano J, Capovilla M, Trevizoli P, Engelbrecht K, Bahl C, Barbosa J (2016) Development of a novel rotary magnetic refrigerator. Int J Refrig 68:187-197. https://doi.org/10.1016/j.ijrefrig.2016.04.005.

192. Benedict M, Sherif S, Beers D, Schroeder M (2016) Design and performance of a novel magnetocaloric heat pump. Sci Technol Built En 22(5):520-526. https://doi.org/10.1080/23744731.2016.1185889.

193. Park I, Kim Y, Jeong S (2013) Development of the tandem reciprocating magnetic regenerative refrigerator and numerical simulation for the dead volume effect. International Journal of Refrigeration 36(6):1741-1749. https://doi.org/10.1016/j.ijrefrig.2013.03.012. 
194. Engelbrecht K, Bahl C, Nielsen K (2011) Int J Refrig 34(4):1132-1140. https://doi.org/10.1016/j.ijrefrig.2010.11.014.

195. Kolano R, Kolano-Burian A, Hreczka M, Polak M, Szynowski J, Tomaka W (2016) Magnetocaloric Cooling Device with Reciprocating Motion of the Magnetic Field Source. Acta Phys Pol A 129(6):1205-1209. https://doi. org/10.12693/aphyspola.129.1205.

196. Romero GJ, Ferreiro GR, Carbia CJ, Romero GM (2013) Experimental analysis of a reciprocating magnetic refrigeration prototype. Int J Refrig 36(4):1388-1398. https://doi.org/10.1016/j.ijrefrig.2013.01.008.

197. He X, Gong M, Zhang H, Dai W, Shen J, Wu J (2013) Design and performance of a room-temperature hybrid magnetic refrigerator combined with Stirling gas refrigeration effect. Int J Refrig 36(5):1465-1471. https://doi. org/10.1016/j.ijrefrig.2013.03.014.

198. Christiaanse T, Brück E (2014) Proof-of-Concept Static Thermomagnetic Generator Experimental Device. Metall Mater Trans 1(1):36-40. https:// doi.org/10.1007/s40553-014-0006-9.

199. Gottschall T, Skokov K, Fries M, Taubel A, Radulov I, Scheibel F, Benke D, Riegg S, Gutfleisch O (2019) Making a Cool Choice: The Materials Library of Magnetic Refrigeration. Adv Energy Mater 9(34):1901322. https://doi. org/10.1002/aenm.201901322.

200. Gutfleisch O, Gottschall T, Fries M, Benke D, Radulov I, Skokov K, Wende H, Gruner M, Acet M, Entel P, Farle M (2016) Mastering hysteresis in magnetocaloric materials. Philos Trans Royal Soc A 374(2074):20150308. https://doi.org/10.1098/rsta.2015.0308.

201. Pulko B, Tušek J, Moore J, Weise B, Skokov K, Mityashkin O, Kitanovski A, Favero C, Fajfar P, Gutfleisch O, Waske A, Poredoš A (2015) Epoxy-bonded La-Fe-Co-Si magnetocaloric plates. J Magn Magn Mater 375:65-73. https://doi.org/10.1016/j.jmmm.2014.08.074.

202. Liu J, Gottschall T, Skokov K, Moore J, Gutfleisch O (2012) Giant magnetocaloric effect driven by structural transitions. Nat Mater 11(7):620-626. https://doi.org/10.1038/nmat3334.

203. Salazar-Jaramillo D, Álvarez-Alonso P, Lázpita P, Sánchez LJ, Gorría P, Blanco J, Chernenko V (2018) Magnetocaloric Effect in Specially Designed Materials. In: El-Gendy AA, Barandiarán JM, Hadimani RL (ed) Magnetic Nanostructured Materials. Elsevier, Amsterdam, p 199-244. https://doi. org/10.1016/B978-0-12-813904-2.00007-3.

204. Moore J, Klemm D, Lindackers D, Grasemann S, Träger R, Eckert J, Löber L, Scudino S, Katter M, Barcza A, Skokov K, Gutfleisch O (2013) Selective laser melting of $\mathrm{La}(\mathrm{Fe}, \mathrm{Co}, \mathrm{Si}) 13$ geometries for magnetic refrigeration. J Appl Phys 114(4):043907. https://doi.org/10.1063/1.4816465.

205. Loh G, Pei E, Harrison D, Monzón M (2018) An overview of functionally graded additive manufacturing. Addit Manuf 23:34-44. https://doi. org/10.1016/j.addma.2018.06.023. 
206. Bandyopadhyay A, Heer B (2018) Additive manufacturing of multi-material structures. Mater Sci Eng R Rep 129:1-16. https://doi.org/10.1016/j. mser.2018.04.001.

207. Pfaff A, Jäcklein M, Hoschke K, Wickert M (2018) Designed Materials by Additive Manufacturing-Impact of Exposure Strategies and Parameters on Material Characteristics of AlSil0Mg Processed by Laser Beam Melting. Metals 8(7):491. https://doi.org/10.3390/met8070491.

208. Zheng X, Smith W, Jackson J, Moran B, Cui H, Chen D, Ye J, Fang N, Rodriguez N, Weisgraber T, Spadaccini CM (2016) Multiscale metallic metamaterials. Nature Mater 15(10):1100-1106. https://doi. org/10.1038/nmat4694.

209. Mahmoud D, Elbestawi M (2017) Lattice Structures and Functionally Graded Materials Applications in Additive Manufacturing of Orthopedic Implants: A Review. J Manuf Mater Process 1(2):13. https://doi. org/10.3390/jmmpl020013.

210. Tofail S, Koumoulos E, Bandyopadhyay A, Bose S, O’Donoghue L, Charitidis C (2018) Additive manufacturing: scientific and technological challenges, market uptake and opportunities. Mater Today 21(1):22-37. https://doi. org/10.1016/j.mattod.2017.07.001.

211. Dehoff R, Kirka M, Sames W, Bilheux H, Tremsin A, Lowe L, Babu S (2014). Site specific control of crystallographic grain orientation through electron beam additive manufacturing. Mater Sci Tech 31(8):931-938. https://doi. org/10.1179/1743284714Y.0000000734.

Open Access This chapter is licensed under the terms of the Creative Commons Attribution 4.0 International License (http://creativecommons.org/licenses/ by $/ 4.0 /$ ), which permits use, sharing, adaptation, distribution and reproduction in any medium or format, as long as you give appropriate credit to the original author(s) and the source, provide a link to the Creative Commons licence and indicate if changes were made.

The images or other third party material in this chapter are included in the chapter's Creative Commons licence, unless indicated otherwise in a credit line to the material. If material is not included in the chapter's Creative Commons licence and your intended use is not permitted by statutory regulation or exceeds the permitted use, you will need to obtain permission directly from the copyright holder.

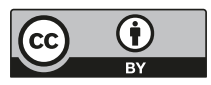

